\title{
Call Your Leader: Does the Mobile Phone Affect Policymaking?
}

\author{
Jahen F. Rezki*
}

December 2018

\begin{abstract}
This paper analyses the impact of Information and Communication Technology (ICT) on policymaking on an Indonesian Village level. In this study, I use data from different waves of the Indonesian Village Potential Statistics (Potensi Desa) to determine whether mobile phone signal strength affects village policies and civic engagement activities. The results indicate that villages with a strong signal are statistically more likely to possess the proper infrastructure and economic programs. Furthermore, mobile phones increase civic engagement, which is consistent with previous studies related to collective action or mass mobilisation. Using the plausibly exogenous variation of lightning strike intensity as the instrumental variable, this study suggests that higher mobile phone signal strength is positively associated with the policies implemented by the village head. This study also demonstrates that ICT has a stronger effect in rural areas. One possible explanation is that mobile phones improve the relative ability for rural people to interact with their leaders. Another potential answer is the fact that there are significant differences between rural village and urban village governments, which could also affect policymaking.
\end{abstract}

Keywords: Mobile Phone, ICT, Village Leader, Indonesia, Accountability, Policy Making

JEL Classification: D78, H7, H4, O1

${ }^{*}$ Department of Economics and Related Studies (DERS), The University of York, UK. Email jfrr500@york.ac.uk. I am deeply grateful to my advisors Giacomo De Luca and Andrew Pickering for their support. I would also like to thank Thomas Cornelissen and Julien Labonne for their helpful comments. Thanks to Thilo Huning for his support. I am thankful to the attendees of CSAE Conference 2018, Nordic Conference on Development Economics 2018, for their feedback. I would also like to acknowledge BPS Statistics Indonesia, LPEM-FEB UI, The IPUMS-International Team and NASA Global Hydrology Resource Centre (GHRC) DAAC for providing the data for this research. Thanks to Indonesia Endowment Fund for Education (LPDP-RI) for their financial support. All errors are my own. 


\section{Introduction}

The role of media and the rapid growth of information and communication technology (ICT) have become increasingly significant over the years. The development of ICT has been documented by Aker and Mbiti (2010), who explains the growth of mobile phone adoption and its impacts on Africa's economic development. The World Bank (2016) describes the extensive growth of ICT throughout developing countries. Nonetheless, studies on the impact of ICT in policymaking are limited. The majority of previous studies focus their research on the impact of media (e.g. television, radio, newspaper) on voter turnout or political accountability (Cook et al., 1983; Besley and Burgess, 2002; Strömberg, 2004b; Olken, 2009; Snyder Jr and Strömberg, 2010; Gentzkow et al., 2011; Enikolopov et al., 2011; Aker et al., 2017). To my knowledge, studies on the impact of ICT, especially mobile phones, on policymaking are scarce. ${ }^{1}$

Indonesia is an ideal natural laboratory for this study because, not only had the country recently democratised and become a more decentralised country after being led by President Suharto for 32 years, but also because ICTs (especially mobile phones) have been growing at an increasingly higher rate. In 2002, only 11.7 million people owned mobile phones, while in 2016 almost 385.5 million people owned mobile phones (See Figure 1). Moreover, Law No. 36/1999 on telecommunication promoted the liberalisation of ICT sectors in Indonesia, which led to an increase in the number of telecommunication providers. Consequently, the cost to use and connect to a mobile network decreased significantly (Lee and Findlay, 2005).

In terms of political context, the introduction of Law No. 22/1999 on regional administrations, followed by Law No. 6/2014 on village administrations, increased the power of local administrative as well as village governments. These laws were introduced to ensure village governance and to improve community participation at the village level. Indonesia has a substantial number of villages. In 2014, there were around 82,190 villages across the country. Moreover, local governments have shown an

\footnotetext{
${ }^{1}$ Several studies have investigated the role of mobile phones in developing countries, such as: Aker et al. (2017) on the role of mobile phones and newspapers in voting intention in Mozambique, Jensen (2007) on the effect of mobile phones in the fisheries sector in South India, Aker (2010) on the impact of mobile phones on agriculture markets in Niger and Bailard (2009) on the relationship between mobile phone diffusion and corruption in Namibia.
} 
increase in responsibility, according to Martinez-Bravo (2014) and Martinez-Bravo (2016) who examined the role of local leaders in Indonesia after the country's democratisation. These studies suggest that local leaders play a significant role in implementing policy.

To discuss the role of mobile phone usage in policymaking, I use different waves of data from the village census (Podes), i.e. data from 2008, 2011 and 2014. The dataset used in this study consists of 42,663 number of observations, which are collected from 14,221 villages across 27 provinces, 156 districts and 1,188 sub-districts. Podes provides extensive information about the village characteristics; It has data related to villagelevel administrations, village economic activities, village geographical conditions, etc. The data also provides information about the ICT development in the village (e.g. signal strength, number of households with fixed-line subscription, number of internet cafes, number of public phones, etc.) Therefore, I am able to investigate the role of mobile phone usage in in policymaking and collective action at the village level in Indonesia.

I use the binary variable to represent signal strength coverage at the village level; This is the main explanatory variable. The data is also retrieved from the Podes dataset. In this study, I only focus on the impact of mobile phones via text messages and/or phone calls. Therefore, the effect of social media or internet usage will not be elaborated. I employ a linear probability model and a logistic model to estimate the impact of signal strength on policies.

A potential problem with using signal strength is the higher probability that signal strength is non-random, which could bias the estimation results. Areas with better infrastructure and larger populations tend to have better signal strength, because the telecommunication sector invests heavily in these areas. A study by Buys et al. (2009) reveals that mobile phone signal depends on the presence of cell tower, size of the population, cost of maintaining the tower, cost of installing the tower and the national competition policy. Another potential problem is related to the measurement error of the signal strength variable, which could affect the estimation results in this study.

To address this concern, I employ an instrumental variable strategy by using the plausibly exogenous variation of flash rate (or lightning strike) intensity at the village 
level. Areas with greater instances of lightning strike tend to have less telecommunication infrastructure, which could result in slower connectivity. Given the fact that Indonesia is also located in a tropical area, and that there is significant geographical variation within the country, I expect that flash rate incidences would affect signal strength quality. Using data from the National Aeronautics and Space Administration (NASA), I show that areas with higher lightning strike incidence have lower signal strength. A one standard deviation increase in lightning strikes reduces the signal strength by 0.03 point or 0.07 point.

I also estimate the model using propensity score matching (PSM), based on the distance between observable geographical and demographic covariates. As has been observed by Rosenbaum and Rubin (1983), under the unconfoundedness assumption, the average treatment effect between the treatment group and the control group is characteristically causal. ${ }^{2}$ One of the benefits of using this method is that matching based on the same geographical matched covariates significantly reduces the possibility of selection bias (Heckman et al., 1998).

This paper finds that higher signal strength is associated with an increased likelihood of infrastructure programs. The results are robust for different types of estimation methods. In terms of the magnitude, I find that villages exhibit a 0.37 point increase in the probability of having an infrastructure program if the village has strong signal strength. Moreover, the same patterns are also observed for the economic program. I also find that higher signal strength increases the likelihood of having an economic program by 0.52 points. Finally, this study shows that mobile phone usage increases the probability that a village will have a civic engagement program. Villages with strong signal strength are more likely to engage in civic activities compared to villages with weak signals or no signal. The coefficient from the two-stage least square estimation indicates that higher signal strength is associated with an increase of 1.59 points in civic engagement activities.

As the types of villages in Indonesia differ greatly depending on location, urban (Kelurahan) or rural (Desa), I investigated whether signal strength has heterogeneous

\footnotetext{
${ }^{2}$ See also Athey and Imbens (2017) for further explanations.
} 
effects. Signal strength is estimated to have a stronger influence in rural villages than in urban villages, especially with regard to infrastructure programs. One potential explanation is that the different types of village governments are run differently: desa in rural areas the village head is elected by the people and, in urban areas, kelurahan the village head is appointed by the district and sub-district governments. Another possibility is that inhabitants in urban areas have alternative sources for collecting information. Therefore, rural villages would benefit significantly from the introduction of ICTs.

Thus, I propose several mechanisms that explain why mobile phones affect policies. First, mobile phone signal coverage affects villagers' ability to call their leader. If the signal is strong, it becomes easier for villagers to inform their leader about their needs. Therefore, people will use their mobile phone more frequently, increasing mobile phone usage. We assume here that telecommunication consumption is a normal good, and therefore improved signal strength increases individuals' consumption of telecommunication services.

Second, mobile phones appear to be the primary information exchange devices among villagers. Once the villagers become aware of a policy implemented by another village's leaders, they will increase the pressure on their leader to adopt the same policy. I explore the potential of spillover effects from neighbouring villages, and find that signal strength in a neighbouring village will affect a village head's policies.

The main contribution of this paper is to empirically test the role of mobile phones in policymaking. To my knowledge, there is no study that investigates the effect of mobile phone usage on a local leader's decision-making. However, previous studies have focused heavily on the impact of mass media in developed countries, such as in the U.S. (Strömberg, 2004b; Snyder Jr and Strömberg, 2010; Gentzkow et al., 2011), as well as less developed countries Besley and Burgess (2002) like India, Olken (2009) Indonesia and Reinikka and Svensson (2011), Grossman et al. (2014) and Grossman et al. (2016) Uganda. The distinct differences between a developing country and a developed country in terms of ICT adoption and infrastructure, as well as the quality of the government, could be an interesting topic of research. This study fills the gaps 
on the importance of mobile phone usage, not only to increase political participation, but also to improve policies and political leaders' decisions. This study explores the extent to which mobile phone usage affects policies, and in which place it significantly contributes. This paper is able to isolate the endogeneity concern of mobile phone adoption by using a relatively new instrument (e.g. lightning strike) to examine the causal relationship between mobile phones and policies (Manacorda and Tesei, 2017). Finally, this study could explain village leaders' behaviour, which differs from that of other elected and/or appointed policymakers.

The rest of the paper proceeds as follows: Section 2 reviews the relevant literature, section 3 provides some institutional background covering both the regulation and political context, as well as the development of ICT in Indonesia. Section 4 presents the theoretical framework and section 5 describes the data specifications. The results of this study are explained in section 6, and section 7 discusses the potential mechanisms of mobile phone effects on policies. Finally, section 8 concludes this study.

\section{Literature Review}

Studies on the importance of media and information in political economy literature have emerged in recent decades, ${ }^{3}$ Nevertheless, the majority of previous studies focus more on the impact of mass media on policymaking.

The important role of ICT in government policies has yet to be explored extensively. Extensive research on the impact of ICTs predominantly investigates the role of mobile phones in agricultural sectors and political mobilisation. Studies related to the role of mobile phones in agricultural sectors were initiated by Jensen (2007), which investigated the role of mobile phone adoption in fisheries in South India. This study has found that, based on micro-level survey data, introducing mobile phones in Kerala, the South

\footnotetext{
${ }^{3}$ Cook et al. (1983) and initiated studies on the impact of media in policymaking. The study uses an experimental approach to address the impact of media on the public, policymakers, interest groups and policy. The study finds that the media plays a significant role in shifting or changing issues that are a priority for both the public and the government. However, the study observes that change in policy is not caused by the news, but rather the cooperation between journalists and policymakers. Studies investigating the role of media in the political economy, specifically with regard to elections, were initiated by Lazarsfeld et al. (1944) and Berelson (1954). These studies observe that mass media, such as the radio and newspapers, has a marginally small effect on voting intention.
} 
Indian fisheries sector, reduces price dispersion. By allowing fisherman to search for information on fish prices and perform spatial arbitrage, mobile phone adoption increases the fishermen's profits and decreases consumer prices.

Aker (2010) has also performed a similar study on the agriculture market in Niger. Based on market and trader level data from 1999 to 2007, this study confirms that mobile phone coverage in Niger reduces agricultural price dispersion. The effects of mobile phone coverage are significantly stronger in remote areas and markets that are connected by unpaved roads. However, unlike the study conducted by Jensen (2007), only traders' welfare increased. This is possible due to the characteristic differences between fisheries markets and agricultural markets.

In addition, Aker and Fafchamps (2014) have extended the previous study by Aker (2010). His study investigates the impact of mobile phone coverage on producer prices in Niger by combining agricultural datasets from 1999 to 2009. It has been observed that mobile phone coverage reduces price dispersions on producer prices. However, decreases in price dispersion only reduce the annual price for certain products (e.g. cowpea)

This study also contributes to the research related to the role of ICT in political mobilisation that has been steadily growing in recent decades. For example, Pierskalla and Hollenbach (2013) has studied the effect of cell phones on the organised violent accidents that occur throughout Africa. The study has found that the availability of cell phone coverage is positively associated with an increase in political violence. As a result of better phone coverage, rebel group become more well-informed, which increases their collective action.

On the other hand, Shapiro and Weidmann (2015) has found opposing results in the case of Iraq. Indeed, his study indicates that an increase in the number of cell phone towers in Iraq significantly reduces the amount of violence. They argue that this could be because better cell phone towers help the U.S. and Iraqi armies prevent terrorist attacks, due to their improved ability to gather information about the potential attack.

A recent study by Manacorda and Tesei (2017) has explored the role of ICTs on political mobilisation using cross country data. Employing extensive datasets for the 
African continent between 1998 and 2012, this study demonstrates that mobile phone coverage is exceedingly instrumental to increasing protest mobilisation during an economic crisis. The study further argues that mobile phones make two significant contributions: as a way of informing individuals about current economic conditions and as way of informing people about upcoming or nearby political protest events. To address potential endogeneity problems, the study also introduces the lightning rate data collected from the National Aeronautics and Space Administration (NASA) as an instrument for analysing mobile phone coverage.

This study is related to the previous research on the effects of media on policies. A study conducted by Strömberg (2001) was the first to provide a theoretical model related to the role of media on public policy. This study reveals that the information received from mass media significantly contributes to, inter alia, political competition, lobby groups, political business cycle and policy. Extending the same model, Strömberg (2004a) has developed a new theoretical model, and argues that mass media competition increases the amount of news provided to larger audiences, e.g. taxpayers, to increase profits; Thus, these news outlets tend to ignore news related to small audiences. The number of news channels greatly affects public policy, and tends to be biased in favour of the issues presented by the mass media.

A theoretical model was further developed to examine the impact of media coverage on policies. This model, introduced by Prat and Stromberg (2013), shows that when there is a surge in the intensity of news related to specific issues, the number of well-informed citizens increases. Moreover, better access to information increases both voters' responsiveness to certain issues and government spending. Finally, based on this model, an increase in information is associated with an increase in government performance, which is followed by a higher share of the votes for the incumbent if their competency on a certain issue is relatively better than their challenger.

Several studies have attempted to investigate the effect of well-informed voters on policies in specific countries. For example, Besley and Burgess (2002) theoretically and empirically investigated the effect of well-informed voters on the government policies in India. Using data on the state governments in India between 1958 and 1992, this 
study has found that state governments with higher newspaper circulation are more responsive to a decline in food production, and are more likely to increase spending on calamity relief and expand public food distribution. Thus, this study suggests that governments are more responsive to informed voters.

The same results were observed during the New Deal Program (1933-1935) in the US (Strömberg, 2004b). Examining the data on the amount spent by the Federal Emergency Relief Administration (FERA) in U.S. counties between 1920 and 1940 and the expansion of radio presence, this study has found that governors sent more aid to counties with a higher number of radio listeners. This paper addresses the potential endogeneity problem by considering the quality of radio reception and share of woodland. This study has also observed that the radio effects are larger in rural areas. Thus, this study suggests the introduction of the radio increased rural citizens' ability to influence government transfers.

A further study conducted by Snyder Jr and Strömberg (2010) has investigated the impact of newspaper coverage in the US. This study has found that voters living in areas with higher press coverage of their local congressmen will be better informed about their representatives, and will also be more likely to vote during the election. Indeed, higher press coverage affects a congressman's performance. Furthermore, areas with higher press coverage receive more federal aid. ${ }^{4}$

Finally, Reinikka and Svensson (2011) has investigated whether providing information related to education grants in the newspaper could reduce the possibility of public funds capture. Using administrative and survey data from Uganda, this study has found that access to newspapers reduces the capture of education grants, and leads to an increase in learning outcomes and primary school enrolment rate. This paper also suggests that media plays a significant role in monitoring policymakers' policies and improving accountability.

This paper is also related to another potential channel in which mobile phone usage

\footnotetext{
${ }^{4}$ Study by Strömberg (2016) and Strömberg (2015) have extensively studied the impact of media on politics. Moreover, Enikolopov and Petrova (2016) has also provided a comprehensive analysis on the causes and impacts of media capture - the condition where the government or special interest groups have the power to control the mass media. DellaVigna and Gentzkow (2010) has also conducted comprehensive literature surveys on the effects of media as a tool to persuade people.
} 
affects the likelihood that voters will interact with their leaders. Grossman et al. (2014) and Grossman et al. (2016) have investigated the role of ICT on the probability that citizens will call their parliament members in Uganda. Both studies have suggested that the introduction of ICT reduces the barrier for citizens to interact with their representatives and increases their political participation. Moreover, Grossman et al. (2014) has observed that marginalised people (e.g. women and poor people) will receive more benefits as a result of easy access to telecommunication and will, thus, be more likely to contact their representatives. Furthermore, Grossman et al. (2016) has also suggested that implementing a mobilising strategy (e.g. sending texts to voters and encouraging them to participate in political engagement) increases the probability that voters will contact their elected leaders.

Within the context of Indonesia, studies that investigate the role of media in policymaking are limited. One such study, conducted by Olken (2009), has explored the impact of television and radio on social capital. Examining data collected from villagelevel governments in Eastern and Central Java, this study has found that improved television and radio signal reception decreases the amount of social participation at the village level, because people consequently spend more time listening to the radio or watching television. Furthermore, the introduction of television and radio have no significant impact on the number of village meetings or creation on infrastructure, which are the proxies for village governance.

This study is also closely related to the role of the village leader in Indonesia. Martinez-Bravo (2014) has observed that villages in which the local leader was appointed by Suharto's regime tend to vote for Suharto's party (Golongan Karya/Golkar). This study also reveals that the appointed village head's decisions are strongly aligned with higher level government policies. Furthermore, Martinez-Bravo (2016) has documented an extensive study on the role of the village leader in Indonesia, especially related to school construction and development projects in Indonesia. By combining data from different waves of village census (1986-2003) in Indonesia, specifically for villages located in Java, this study finds that an educated leader is associated with a higher number of projects funded by the village budget. Furthermore, educated leaders 
also spend less time finishing development projects, since, as the evidence suggests, educated village heads are more effective project managers.

Based on the above discussion, there is an abundance of evidence that media affects government policy and political mobilisation. Nevertheless, the majority of extant studies focus on mass media, while studies that investigate the role of ICT, especially using micro-level data, are limited. Hence, the present study aims to determine whether technology adoption has a similar impact in newly democratised countries, such as Indonesia.

\section{Institutional Background}

\subsection{Village Regulation and Political Context}

In 1999, after Suharto's presidency, a major change occurred in the process of democratisation and decentralisation in Indonesia. During the Suharto regime (New Order Era), all decisions were made by the central government, and local governments were controlled and monitored by the central government. ${ }^{5}$ Law No. 22/1999 on regional administrations was introduced to provide major reforms in terms of transferring decision-making powers to the district and village governments (Antlöv, 2003; Bebbington et al., 2006). ${ }^{6}$

There are many reforms related to local governments and also village-level administrations. As a result, villages are more autonomous. Indeed, villagers may now elect their village head and are allowed to run their village-owned enterprises. Before 1999 , the only source of revenue for the village was via transfers from the district or sub-district governments. Moreover, the village now also has more autonomy to accept

\footnotetext{
${ }^{5}$ During President Sukarno's regime, the Indonesian government recognised approximately 250 types of administrative governments and communities. For example, in Java and Bali, there was Desa, Nagari in West Sumatra or Minangkabau, Dusun and marga in South Sumatra (Antlöv, 2003). However, the variation of these types of governments did not match the leadership style of his successor, President Soeharto, who preferred to exercise strong control over the local governments. Therefore, in 1979, the government introduced Law No 5/1979, which aimed to impose the same type of institutions for almost all across the countries. Village-level governments would be controlled and supervised by a higher authority, therefore the village head did not have any ability to implement their own agenda. All decisions were made following the advice of the district or sub-district governments.

${ }^{6}$ The discussion in this subsection is based on Evers (2000), Antlöv (2003), Bebbington et al. (2006) and Antlöv et al. (2016).
} 
or reject programs provided by the central government (Antlöv, 2003).

Another reform provided by Law No. 22/1999 is the accommodation of cultural diversity of Indonesia's society. Villages can be managed through original customs and local traditions. Villages also have village councils (Badan Perwakilan Desa, BPD) that consist of 5 to 13 members and serve as a democratic village body. These village councils have the power to introduce legislation, accept the village budget, and also monitor the village government. In terms of checks and balances, village leaders have to submit a report on an annual basis to the BPD regarding his or her activities. Therefore, village heads are accountable for the villages' inhabitants, which is quite different from the previous law which stated that the village leaders would report their activities to the district or sub-district governments (Antlöv, 2003). ${ }^{7}$

\subsection{Village Administrative Institutions}

Indonesia has five levels of administrative structure: central government, provinces government, districts government, sub-districts government and village-level government. In 2014, there were 34 provinces in Indonesia. Each province was divided into two districts: Kota an urban district (98 in 2014) Kabupaten or a rural district (416 in 2014) (Ministry of Home Office, 2014). Each district was then further divided into subdistricts Kecamatan, and finally, the sub-districts were divided into villages, which are the lowest administrative level. Similarly, with districts, there are two types of villages: Desa rural and Kelurahan urban. In 2014, there were 81,190 villages in Indonesia, of which 72,949 villages, or around 89\%, are Desa and 8,412 villages, or 10\%, are Kelurahan (Central Bureau of Statistics, 2014).

Desa and Kelurahan villages are characteristically different, especially in regard to

\footnotetext{
${ }^{7}$ Recently, the government of Indonesia introduced Law No.6/2014 on village administrations in Indonesia. This is the extended version of the previous regulation related to village governments (Lewis, 2015; Antlöv et al., 2016). The bill attempted to empower village governance, reduce inequality between villages and ensure the effectiveness of the proposed development programs. The major reforms in this law are related to central government transfers. The central government will allocate up to $10 \%$ of the national budget for transfers to village governments. Moreover, to ensure good governance of the village administrations, this law also increases the power of BPD and introduces village assemblies, which are government bodies that approve or reject the programs proposed by the village heads (Antlöv et al., 2016). The establishment of a village assembly also encourages community participation in the village. Therefore, decision-making at the village level heavily relies on communication between the village communities and the village leaders.
} 
government structure. The village head is elected by villagers every six years with a term limit of three periods. On the other hand, the kelurahan village leader is appointed by the head of the district government. Furthermore, everyone can become a village leader in the Desa. The Kelurahan leader, however, must be a civil servant. Therefore, Desa and Kelurahan are expected to have heterogeneous effects in this study, due to the differences in government structure.

In terms of public goods provisions, villages can provide the goods funded from their budget or from other sources of funding, such as upper-level governments (National Development Planning Process or P5D) and donors (e.g. PNPM-Mandiri managed by the World Bank). ${ }^{8}$ In 2014, mean village revenues were around Rp 88.8 million (US \$5,920), and the total village revenues were around Rp 350.57 million (US \$ 23,371). ${ }^{9}$ Moreover, almost $48 \%$ of the infrastructure programs (e.g. roads, bridges, schools, sanitation, clean water, electricity, clinics, markets and irrigation) implemented at the village level were funded by the village's own budget (Central Bureau of Statistics, 2014). One way for a village leader to increase spending on public goods is by reducing spending on administration (e.g. salary, meeting expense, office equipment, etc.) and increasing spending on infrastructure (Martinez-Bravo, 2016).

\subsection{Telecommunication Sectors in Indonesia}

The development of ICT, especially in the telecommunication sectors in Indonesia, cannot be separated from the Asian financial crisis of 1997-1998. One of the recovery packages proposed by the International Monetary Fund (IMF) stated that the Government of Indonesia had to rescind the monopoly power over Indonesia's state-owned telecommunication company, PT Telekomunikasi Indonesia (Telkom), and remove restrictions on foreign investment. ${ }^{10}$ Furthermore, Indonesia joined the World Trade Organisation's Agreement, by which one of their commitments was to urge the coun-

\footnotetext{
${ }^{8}$ See Evers (2000) and Martinez-Bravo (2016) for further information.

${ }^{9} 1$ US $\$ \approx \operatorname{Rp} 15000$

${ }^{10}$ From 1964 to 1989, Indonesia had two state-owned telecommunication companies, PT Telekomunikasi Indonesia (Telkom) and PT Indonesian Satellite Corporation (Indosat). Telkom exclusively provided all domestic services, while international services were monopolised by Indosat. In 1989, due to a lack of funding in the telecommunication sector, the government introduced Law No. 3/1989, which encouraged private investments and established a partnership between Telkom and Indosat for the first time.
} 
try's members to liberalise the telecommunication sectors under the supervision of an independent regulator. Moreover, the agreement also endorsed the eradication of Telkom's monopoly in the domestic, long-distance and international telephone markets (Lee and Findlay, 2005).

In 1999, the government of Indonesia passed a new law related to the telecommunications sector (Law No.36/1999), which introduced two important regulations. First, the government would introduce duopoly markets between Telkom and Indosat, and slowly introduce private telecommunications companies into the markets. Second, the restrictions for foreign companies to enter the telecommunication market would be removed (Lee and Findlay, 2005). The (partial) liberalisation of the telecommunication sector resulted in competition between six different providers. In 2016, the largest Indonesian telecommunication companies, based on their market share, were Telkomsel (Telkom subsidiary company) with $77.6 \%$ share, XL Axiata with $11.2 \%$ share, Indosat with $6.2 \%$ share and Hutchison Tri and Smartfren with a combined 5\% share (PT Telekomunikasi Selular, 2016). However, there no further major reforms have been implemented in Indonesia's telecommunication sector, and there is no significant link between the post-authoritarian period and reform in this sector (Baulch, 2017).

Even though no further reform has been made in the telecommunication sector, it cannot be denied that Law No.36/1999 has significantly transformed Indonesia's ICTs sector. By increasing the number of competitors and providers, the cost to use and to connect over mobile networks has dropped significantly (Lee and Findlay, 2005). As a result, many new telecommunications devices have emerged in the market, making mobile phones more affordable for low and middle-class individuals.

Since 2010, almost all Indonesian people have had access to telecommunication, and especially to mobile phones. From Figure 1, it is possible to observe the development of ICT subscriptions in Indonesia. The growth of mobile phone adoption in Indonesia started to surpass the growth of the fixed telephone line in 2002; In 2002, 11.7 million people owned a mobile phone, compared with the 7.7 million people who owned a fixed telephone line. By 2016, the number of people who owned a mobile phone increased to 385.5 million, compared to only 10.3 million people who owned a fixed telephone 
line. Thus, it is clear that mobile phone subscriptions have grown significantly since 2000, while fixed-line subscription has been steadily declining since 2011. Based on the Intercensal Population Survey (SUPAS), conducted by the Indonesia Central Bureau of Statistics, in 2005, approximately $23 \%$ of the population owned a telephone or mobile phone. According to the 2010 Population Census, approximately $76 \%$ of the population owned a mobile phone (Minnesota Population Center, 2017). ${ }^{11}$

ICT infrastructure has become a main priority for the government of Indonesia. However, ICT infrastructure is developed slowly in Indonesia, due to a number of problems that the country faces, especially a lack of access to extensive investment. To increase access to telecommunication for all parts of Indonesia, in 2005 the government initiated The Indonesian Broadband Plan (IBP), called the Palapa Ring Project, which sought to increase connectivity between islands in Indonesia, both in western and eastern parts, and especially remote areas in Indonesia. The target of this project is that, by the end of 2019, all areas in Indonesia will be covered and connected by ICT infrastructure (Rohman, 2014).

The association between ICT and policymaking in Indonesia has grown progressively stronger. In 2014, the Ministry of Villages, Disadvantaged Regions and Transmigration introduced call centres that would provide an opportunity for villagers to report their villages' needs or problems. Moreover, one recent example is when the former Governor of Jakarta, Basuki Tjahaja Purnama (Ahok), made his mobile phone number public to allow citizens to call or text him if they have a problem that requires government attention. Jakarta has also introduced Qlue, which is a mobile application that can report and monitor problems faced by Jakarta citizens. ${ }^{12}$

\footnotetext{
${ }^{11}$ See also the expansion of mobile phone subscriptions at the village level between 2005 and 2010 in Figure 2 and Figure 3. The figures demonstrate that mobile phone subscriptions have grown significantly. However, in some parts of Indonesia, especially in Eastern Indonesia, the subscription rates were consistently lower for both years. One possible explanation is that the quality of the ICT infrastructure in these areas is relatively poorer compared to the rest of the country (See Figure 4, Figure 5 and Figure 6.

${ }^{12}$ See the website at http://qlue.co.id/site/
} 


\section{Conceptual Framework}

In this study, two mechanisms are used to explain how ICT, specifically mobile phones, affect government policies or development. This study focuses only on the effect of mobile phones via calls or text messages to the village leader regarding policies. Therefore, I do not consider the effects of internet or social media in this mechanism. The mechanisms in this study are motivated by the previously explored studies, which were detailed in section 2. Section 7 provides an extensive discussion on the mechanism of this study.

Mechanism 1 Mobile phones increase the incentive for citizens to report or request their needs to the village leader.

The first mechanism explains the direct link between mobile phones and the village leader's policies. As has been observed by Grossman et al. (2016) and Grossman et al. (2014), mobile phones reduce the barriers to interact with government representatives, and therefore increase voters' engagement with them. Adopting the same mechanism, this study assumes that villagers use their mobile phones to call or send a text message to their village leader. Therefore, it is easier for a villager to attract their leader's attention when they have better access to ICT, i.e. better ICT infrastructure, and better signals.

Villagers who are living in areas with better signal strength can maximise the usability of their mobile phone to improve their welfare. On the other hand, villagers who are living in areas with weak signal strength need to meet their leaders directly to inform them of their difficulties. Therefore, it increases the cost required to inform the village leader of their problems, and consequently decreases the village leader's ability to know what kind of policy the villagers need. Thus, the leader is less likely to implement effective policies, due to a lack of information about the villagers' problems.

Another possible explanation is that better signal is followed by higher mobile phone subscription rates. Figure 2 and Figure 3 illustrate that areas stronger signal (See Figure 4, Figure 5 and Figure 6) have higher mobile phone subscriptions compared 
to area with weak signal. Therefore, villages with better signal strength exhibit an increase in the number of messages sent from villagers to their leaders. This results in an increase in villagers' consumption of telecommunication products.

From the village leader's perspective, better ICT infrastructure makes them more aware of problems in their village. Because village leaders become better informed, this affects their policy decisions. As previously mentioned, Strömberg (2004b) has found that during the new deal program in the US, governors would increase their spending in areas with higher radio coverage. Similarly, Besley and Burgess (2002) has also found a similar condition in India. Therefore, I expect ICT to affect village leaders' policies.

It is also expected that there will be heterogeneous effects of ICT between rural and urban villages. Strömberg (2004b) has observed that higher radio penetration has a significant effect on rural areas in the US. Because Indonesia has two types of village governments, I also expect that villages with elected leaders will be significantly impacted by the expansion of ICT. Martinez-Bravo (2014) has shown that villages with appointed leaders tend to exhibit clientelistic spending, which affects voters' welfare.

Mechanism 2 Mobile phones are used to transfer information among villagers and, therefore, increase pressure on village leaders to perform well.

The second mechanism explores the exchange of information between villagers who live within the same villages, and between villagers who live in different villages. Studies have found that ICT increases the exchange of information among the population, which consequently increases political mobilisation and pressure on the government (see, inter alia, Manacorda and Tesei (2017); Pierskalla and Hollenbach (2013); Shapiro and Weidmann (2015)).

Suppose that the leader of a neighbouring village implements a policy to improve infrastructure. The villagers of neighbouring villages would learn of this policy by communicating via their mobile phones, and thus increase pressure on their own leaders to implement the same policy. This transfer of information is accomplished 
with better signal strength. Villages with bad ICT infrastructure will not be able to learn about their neighbours' policies, thus reducing the probability that the villagers will ask for such policies from their village head.

Another possible mechanism considers within-village communication. Suppose that a villager discovers that the village leader has done rent seeking behaviour. Using their mobile phone, they can distribute this information to their neighbours within the village. As a result, the villagers could mobilise and increase pressure on their leader. However, this is more likely in villages with better ICT infrastructure, because information can be exchanged with more relative ease than in villages with poor ICT infrastructure.

Moreover, it could also affect the possibility that the village leader will be re-elected. Since village leaders are elected by the villagers (only in desa), ICT can also affect their chances of being re-elected. Villages with better ICT infrastructure are better informed about their leader's performance. This mechanism is also motivated by Strömberg (2004a), Strömberg (2004b) and Snyder Jr and Strömberg (2010), who have found that the amount of information voters receive affects their vote as well as voter turnout.

In accordance with these mechanisms, I have developed the following three hypotheses on the role of ICT in policymaking.

Hypothesis 1 Infrastructure and economic policies improve with ICT.

Based on mechanism 1 and mechanism 2, it is expected that an increase in the quality of ICT will increase the likelihood that village leaders will improve their policy decisions for development purposes. In this study, I expect that villages with better ICT infrastructure will be more likely to implement policies regarding infrastructure and the economic sector.

Hypothesis 2 Civic engagement increases with ICT.

Similar to hypothesis 1, I expect that better ICT infrastructure will increase civic engagement due to the ease with which villagers can exchange information. Therefore, villagers with better ICT are more likely to be civically involved. Hypothesis 2 differs from Olken (2009), which has found that radio and television have a negative impact on 
social participation in Indonesian villages. However, while people cannot participate in other activities while listening to the radio or watching television, mobile phones do not reduce individuals' ability to simultaneously participate in other activities.

\section{Hypothesis 3 ICT has a stronger effect in rural areas.}

The last hypothesis argues that rural areas will benefit from an increase in access to infrastructure due to heterogeneous government and village characteristics between villages in urban and rural areas. It is assumed that people in rural villages would benefit greatly from mobile phone diffusion, since rural villagers, unlike urban villagers, do not have alternative sources for receiving information.

\section{Data and Specification}

The data used in this study are from the Indonesian Village Potential Statistics (Potensi Desa/PODES). These data are collected by the Indonesian Central Bureau of Statistics (Badan Pusat Statistik/BPS) every three or four years. The sample of PODES in every census is $+/-65,000$ villages across the country. Podes is a census that provides information about Indonesian villages' characteristics, such as government administrations, public goods provided in the village, socio-economic characteristics and other comprehensive information. ${ }^{13}$ because each wave has a different focus, however, some variables are not reported on in all waves of the village census.

In this study, I merge three different waves of the village census, collected from 2008, 2011 and 2014. The main problem when constructing this dataset is that The Central Bureau of Statistics in Indonesia uses village identifiers across waves inconsistently. Therefore, some of the villages have a different identifier in different waves. Moreover, the introduction of new villages during the study period is not easily detected. Given the difficulty in merging the dataset with a large number of observations, I chose to use only the villages that are consistently included in all of the waves. Therefore, some of the villages were excluded from the dataset.

\footnotetext{
${ }^{13}$ In every survey, the enumerator collects the answers from a person who works in the village administration, and verifies this information against the village's administrative records. Some measures of public goods, such as the number of schools, health facilities, mosques, and churches, can be easily verified. Therefore, this survey produces accurate information about the village.
} 
The dataset used in this study consists of 14,221 villages, which cover 27 provinces, 156 districts and 1,188 sub-districts. In total, I have 42,663 observations for this study. ${ }^{14}$ Table 1 provides the summary statistics for the data in this study. As previously mentioned, there are different types of government divisions at the village level. In this study, I use a comprehensive sample of villages in Indonesia. However, I will analyse the results by dividing them according to the different types of government, specifically between Desa and Kelurahan.

\subsection{The Dependent Variables}

This study aims to examine whether access to mobile phones increases the number of calls, reports or requests made by the villagers to their village leaders, resulting in an increase in the number of policies implemented. Furthermore, this study examines whether access to a mobile phone reduces or increases social activities at the village level.

I divided the analysis of this study into two main groups: (1) the impact of mobile phones on village leaders' policies and (2) the impact of mobile phones on civic engagement or collective actions. With regard to the first analysis, I used two dummy variables for the dependent variable. The first dummy variable is Infrastructure, which is a binary variable that represents whether the village has an infrastructure program (e.g. building roads, bridges, schools, sanitation, housing, etc.) funded by the village budget. From Table 1, it can be observed that the mean for infrastructure is 0.55 , and that the standard deviation is 0.5 . This finding indicates that only $55 \%$ of the study sample had infrastructure programs during the study period. The mean for infrastructure programs for each survey was: 0.21 in 2008, 0.47 in 2011, and 0.93 in 2014.

The second dependent variable is Economic, which is a dummy variable that represents whether the village has a program to provide grants to people who are going to start a new business or to expand their current business activities. This program also entails training provided by the village governments to increase villagers' skills. Both

\footnotetext{
${ }^{14}$ While the data is not representative across the country, it covers all the major islands and the majority of Indonesia's population. Moreover, to mitigate the potential of selection bias, I also estimated using propensity score matching (PSM) based on geographical matched covariates, which will be explained in section 5.3.
} 
the mean and the standard deviation for this variable are 0.53 . In 2008 , only $28 \%$ of the villages had economic programs, although this number increased to 58\% in 2011, and $72 \%$ in 2014. Unlike infrastructure programs, the descriptive statistic indicates that economic programs are more likely to be implemented at the village level.

For the second analysis, a binary variable on whether the village has civic Engagement activities (gotong royong) (e.g. mutual and reciprocal assistance (Bowen, 1986)) are the dependent variable. Civic engagement or collective action (I will use the term interchangeably) in Indonesia are considered social activities that help others or that organise people to improve the conditions of their neighbourhood. Gotong royong has become a key element of Indonesian political and cultural systems. Indeed, this activity is very important in villages and rural areas, especially for agricultural and economic activities (Bowen, 1986). Therefore, higher civic engagement can be interpreted in two ways: (1) the villages have good community activities and social relationships or (2) the villages lack necessary facilities and infrastructure or have just experienced a natural disaster, and therefore the people are working together to improve their current condition. From Table 1, it can be seen that the mean for civic engagement is roughly 0.47 and the standard deviation is 0.49 . In 2008 , only $16 \%$ of the villages had civic engagement activities. However, this has increased to 0.55 in 2011 and, subsequently, to 0.68 in 2014. Thus, there has been an increase in civic engagement activities during these years.

\subsection{Explanatory Variables}

Previous studies have explored a variety of aspects related to mobile phone usage, such as mobile phone coverage or signal (Manacorda and Tesei, 2017; Shapiro and Weidmann, 2015; Pierskalla and Hollenbach, 2013; Buys et al., 2009; Aker, 2010), mobile phone subscription or penetration (Ahn and Lee, 1999; Gruber and Verboven, 2001) and mobile phone adoption (Jensen, 2007). Publicly available data related to mobile phones in Indonesia is mobile phone signal strength at the village level, which can be collected from Podes. ${ }^{15}$ In Podes, signal strength is divided into three criteria: (1) no

\footnotetext{
${ }^{15}$ Other data related to ICTs in PODES include the number of households with fixed line subscription, the existence of public phones, and the number of internet cafes.
} 
signal, (2) weak signal and (3) strong signal.

In this study, the core explanatory variable is Signal, which is a binary variable that represents the strength of the village's mobile phone signal. Therefore, the value of signal will be zero if the village's signal strength is weak or non-existent. From Table 1, it is evident that the mean for Signal is 0.81 and the standard deviation is 0.48. Thus, almost $81 \%$ of the sample villages in the study have strong signal strength. Between 2008 and 2014, the signal strength improved throughout the villages, whereas the average signal strength was 0.79 in 2008, it became 0.82 in 2014 .

Figure 4, 5 and 6 depict the conditions of mobile phone signal strength in Indonesia from 2008 to 2014. Almost all areas in Java are covered by a strong signal, because the ICT infrastructure in Java is significantly better than on the other islands. Furthermore, the majority of Sumatra also has relatively strong signal. Eastern parts of Indonesia, especially Papua, have poor signal strength, however. This is because the infrastructure quality in the eastern part of Indonesia is generally worse than on the other islands. It is also clear that from 2008 to 2014, signal strength greatly improved, especially in Java and Sumatra. From the image, we can see that almost all major cities in Indonesia, such as Jakarta, Bandung, Surabaya, Medan, Makassar, Pekanbaru, Palembang and Padang, have a strong signal strength.

Some variables that were used as additional explanatory variables include: information about the village leaders, such as gender (i.e. 1 if male, 0 otherwise), years of schooling and age. From Table 1, it can be observed that almost 94\% of the village heads are male; The standard deviation is 0.24 . This data suggests that there is a bias among village leaders in Indonesia towards males.Moreover, most of the village heads only have a high school degree, which is quite low (mean $=12.35$ and $\mathrm{sd}=2.66$ ). Furthermore, the average age of the leader is approximately 44.59 and the standard deviation is 8.13 . The minimum value for leader age is 20 years old and the maximum value is 87 years old. 


\subsection{Specification and Identification Strategy}

In this study, three main econometric methods are used to examine the impact of mobile phone usage on policies: (1) linear probability model (LPM) and (2) logistic model.

The linear probability model is as follows:

$$
Y_{v, t}=\beta_{\text {Signal }_{v, t}}+\gamma X_{v, t}+\theta_{v}+\vartheta_{t}+\epsilon_{v, t}
$$

where $Y_{v, t}$ is the binary dependent variable in the village $v$ at time $t$. Signal $l_{v, d, t}$ is a dummy variable that has a value of 1 if the village $v$ and time $t$ have a strong mobile signal strength, and 0 otherwise; $\gamma X_{v, t}$ represent the vector of control variables; $\theta_{v}$ are the village fixed effects; and $\vartheta_{t}$ are the year fixed effects. The main coefficient of interest is $\beta$, because it estimates the within-village difference in the probability of the dependent variable being $1\left(\operatorname{Pr}\left(Y_{v, t}=1\right)\right)$, between villages with strong and weak signal strengths that exhibit similar characteristics.

The control variables used in this paper are the set of rich datasets related to village-level characteristics, such as variables related to village governance, e.g. male leader (i.e. 1 if male, 0 otherwise), age, years of education; village-level demographic, e.g. number of population, expenditure per capita, main sources of income (i.e. 1 if agriculture, 0 otherwise); and social indicators, e.g. Muslim (i.e. 1 if Muslim majority, 0 otherwise), multi-ethnic (i.e. 1 if more than one ethnicity, 0 otherwise), number of mosques and number of churches. The list of control variables for the village-level demographics is displayed in Table 1.

The second method is the logistic model that is estimated via the following equation:

$$
\operatorname{Pr}\left(Y_{v, t}=1\right)=F\left(\beta_{\text {Signal }_{v, t}}+\gamma X_{v, t}+\theta_{v}+\vartheta_{t}+\epsilon_{v, t}\right)
$$

where $F($.$) is the cumulative standard logistic function and \epsilon_{v, t}$ is an error distributed by the standard logistic distribution. Through the use of this logistic model it is also 
possible to estimate the within-village variation of the signal strength on $\operatorname{Pr}\left(Y_{v, t}=1\right) .{ }^{16}$

\subsection{Instrumental Variable}

The results from the LPM and Logit estimations might be biased, however, because the signal strength variable might not be entirely random. Areas with larger populations or better infrastructure might have better signal strength. Moreover, urban cities could have bad signal strength due to the large number of high buildings in the surrounding the area. This condition could also make signal strength endogenous, because the decision to place buildings might also effect policy choice. Another potential problem that could potentially bias the results is the measurement error of signal strength. The data on signal strength is based on the answers provided by the village administrations and, thus, may not accurately reflect the true condition of mobile phone signal strength.

Although an instrumental variable strategy could be used to solve these potential problems, it is quite difficult to find exogenous variables that would work in this study. As noted by Aker and Mbiti (2010), the problem with ICT studies is that it can be difficult to find a credible instrumental variable. It should satisfy all the conditions to become a credible instrument, which are: (1) uncorrelated with the error term $\epsilon_{v, t}$ in equation (1); (2) correlated with the explanatory variable (signal strength) and (3) not used as the explanatory variables in equation (1) (Angrist and Krueger, 2001; Angrist and Pischke, 2009; Murray, 2006; Wooldridge, 2010).

To address this potential problem, I used the mean of flash rate or lightning strike (I will use this term interchangeably) intensity per $\mathrm{km}^{2}$ between 1998 and 2013 at the village level, interacted by time trend. ${ }^{17}$ The data is available across the world and, in this study, I was able to construct the flash incidence data at the Indonesian village level. Because the data is time invariant, I used the interaction between flash rate intensity for the village $v$ and time trends to allow me to estimate the effects of the

\footnotetext{
${ }^{16}$ Logit and Probit, however, exhibit several limitations when using fixed effects. See Heckman (1979) and Greene (2004) for further explanation.

${ }^{17}$ Data retrieved from LIS 0.1 Degree Very High Resolution Gridded Lightning Full Climatology (VHRFC) https://ghrc.nsstc.nasa.gov/hydro/details/lisvhrfc. This data is provided by the US National Aeronautics and Space Administration (NASA). The data is not available for every year, however Andersen et al. (2012) and Manacorda and Tesei (2017) have determined that a consistent pattern exists for the lightning strike across this period of time. See Cecil et al. (2014) for further information.
} 
instrument on the mobile phone signal strength in the panel data setting. A similar approach has been used by Manacorda and Tesei (2017); They used flash rate incidence as an instrument for mobile phone coverage in Africa.

Hence, the first stage of this estimation is:

$$
\text { Signal }_{v, t}=\alpha_{v, t}+Z_{v, t}+\gamma X_{v, t}+\theta_{v}+\vartheta_{t}+\mu_{v, t}
$$

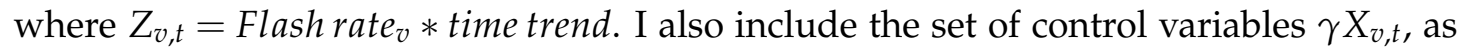
well as village fixed effects $\left(\theta_{v}\right)$ and year fixed effects $\left(\vartheta_{t}\right)$.

Cecil et al. (2014) has suggested that tropical and sub-tropical regions tend to have a higher annual flash rate. Albrecht et al. (2011) has also observed that high flash rates are linked to topographical features. Therefore, Indonesia has a higher flash rate incidence due to its location and geographical characteristics. Figure 7 depicts the variation of lightning strike in Indonesia between 1998 and 2013. Based on the figure, areas in Sumatra have increased incidences of lightning strike. Most of this area is located at a higher altitude. Moreover, some parts in Java also exhibit higher lightning strike incidences. Moreover, there is a high variation across the country, implying that the incidences of lightning strike may explain the variation in signal strength throughout Indonesia. The mean flash rate in Indonesia from 1998 to 2013 was 20.29 flash rate $/ \mathrm{km}^{2}$ (See Table 1). This number is higher than the global flash rate, which is around 2.9 flash rate $/ \mathrm{km}^{2}$, and the average flash rate in the tropic and sub-tropics (10 flash rate $\left./ \mathrm{km}^{2}\right)$.

Thus, lightning strike has a strong relationship with the provision and quality of telecommunication infrastructure. Andersen et al. (2012) has observed that lightning can damage mobile phone transmitters, and thus negatively affect connectivity. Since this can result in less investment in telecommunication towers, which ultimately reduces the quality of mobile phone services, I expect that villages with higher flash rate intensity would have lower signal strength. The underlying assumption here is that flash rate intensity only affects the dependent variables through mobile phone signal strength.

Even though I am relying on the assumption that flash rate intensity is exogenous, 
this assumption might be not true because flash rate also depends on geographical conditions. Moreover, it is possible that a higher intensity flash rate would affect village conditions and, ultimately, affect the policies implemented by the village government. To isolate this, I also included sets of controls and geographical fixed effects. I also performed an additional verification step to determine whether flash rate intensity corresponds with the dependent variables, conditional on a battery of controls and geographical characteristics. This also indicates that the exclusion restriction holds in this study.

\section{Results}

In this section, I discuss the results from the LPM and Logit estimations of equation 1 and equation 2, as well as the results from the matching method. I begin the analysis by discussing the association between signal strength and the policies made by village leaders, as well as the probability of civic engagement activity based on the LPM and Logit estimation results. I also discuss the results from the matching method, based on the fact that this study estimates the differences in the outcome variable between the treatment and control groups for non-experimental data.

\subsection{LPM and Logit Results}

Infrastructure Program Table 2 exhibits the estimation results for the infrastructure program. The dependent variable in this table is the dummy variable, which has a value of 1 if the village has an infrastructure program, and 0 otherwise. Columns (1) - (4) were estimated using a linear probability model and columns (5) - (6) were estimated using a Logit model. All specifications from columns (1) to (5) include village fixed effects. Year fixed effects are included for columns (2) - (6). For columns (4) - (8), I use the interaction between urban and year fixed effects to isolate the variation in ICT coverage within villages located in urban areas, and therefore control for unobservable variables that might be correlated to signal strength. For the logistic model, column 5 depicts the fixed effect logistic regression and column 6 depicts the estimation results 
of the random effect logistic regression.

From Table 2, it is clear that strong signal strength is associated with a higher probability that an infrastructure program will be implemented. The results are robust for all estimation methods. The magnitude is quite large and statistically significant at $1 \%$ when excluding the covariates and year fixed effects. Once I included the year fixed effects and the interaction between the urban and year fixed effects in columns (2) - (4), the magnitudes decreased and were statistically significant at 5\% (in column 4).

Moving to the logit regression results in columns (5) and (6), it is evident that the number of observations is smaller in the fixed effects model than in the random effects model, due to the fact that the logit method excluded villages that do not exhibit variation in the dependent variable. Nevertheless, the results from the fixed effects logit estimation supports the results from the LPM estimation. The random effects estimation, however, does not isolate the within-village variation and may this create potential problems, such as an omitted variable bias. Regardless, the results from column 6 also indicate that better signal strength increases the likelihood of having infrastructure programs.

These results are consistent with the hypothesis in this study that an increase in access to ICT will increase a village leader's incentive to implement policies that are beneficial for the people, such as building roads, school, and other forms of infrastructure. Moreover, an increase in access it ICT also makes it easier for villagers to report their problems to the village leader.

Economic Program The association between signal strength and economic program is presented in Table 3. Based on the LPM results, higher signal strength is associated with higher probability of economic programs. The results are robust for all types of specifications. In column 4, higher signal strength increases the likelihood of having economic programs, and is statistically significant at the $5 \%$ level after considering unobservable village characteristics and time effects, as well as after isolating the village's location. Even though this cannot be interpreted as a causal effect, this result is quite promising. Indeed, it means that signal strength could an important variable 
to increase the probability of better policies implemented by a village leader.

The coefficient from logit estimations in column (5) is relatively higher compared with the LPM results, nonetheless the signs are similar and is statistically significant at $5 \%$ level. Moreover, the result from random effects logit model in column (6) exhibits that higher signal strength increases the likelihood of having economic empowerment programs.

These findings are important because the results of the economic and infrastructure programs in areas with higher and lower signal strength, respectively, remain unchanged after considering the differences between the confounding variables. In terms of magnitude, villages with higher signal strength are more likely to implement economic programs by 1.7 percentage points.

Civic Engagement Table 4 depicts the estimation results for civic engagement, where the dependent variable will have a value of 1 if a village exhibits civic engagement or gotong royong related activities, and 0 otherwise. Columns (1) to (4) present the results from the LPM method. We can observe that villages with higher signal strength have a higher probability of participating in civic engagement activities than villages with a weak signal for all different types of specifications. The results are robust at the $1 \%$ level for column (1) when the model is regressed by excluding year fixed effects and the control variable. It becomes less significant, however, in column 2 when year fixed effects are included in the regression. Once I include the control variables in column (3) and the interaction between urban and year dummies in column (4), the results indicate that higher signal strength is associated with increased likelihood of participating in civic engagement activities.

The results from the fixed effects logit model in column 5 are negative (though insignificant). Nevertheless, in column 6, for the random effects logit model, the results indicate a positive correspondence between signal strength and civic engagement, and are statistically significant at the $1 \%$ level. However, it does not isolate the within-village variations and, thus, might bias the results.

Moreover, the results for civic engagement are quite different than those obtained 
in Olken (2009), which has found that media (such as television and radio) reduce participation in social organisations in Indonesia. Thus, the results of the present study demonstrate that mobile phones can be an effective media tool to inform people about or ask people to participate in civic engagement activities. People can more easily contact one another when they need help or when they want to organise collective activities via mobile phones. This result is consistent with other studies on the positive association between mobile phone adoption and collective action or political mobilisation (Manacorda and Tesei, 2017; Shapiro and Weidmann, 2015; Pierskalla and Hollenbach, 2013).

\subsection{Instrumental Variable}

I performed a two stage least square (2SLS) estimation in this study to address the endogeneity problem with previous estimations. As previously mentioned, the flash rate intensity is used as an instrument for signal strength. Table 5 presents the results from this estimation. The first stage results indicate that a one standard deviation increase in flash rate intensity reduces the signal strength by 1.09 percentage points. The instrument passes the standard test for validity, in which the joint-F statistics for this instrument range from 22.46 to 26.06 , which is larger than the minimum proposed by Staiger and Stock (1997), which is 10.

Column (1) contains the 2SLS estimation results for the infrastructure program, without including control variables, while column 2 includes the control variables. Village and year fixed effects are included in all of these estimations. The results from the 2SLS estimation exhibit a larger magnitude than the LPM and logit regressions, although they are less significant than the results of the LPM. Villages with higher signal strength have a 0.37 -point higher probability of having an infrastructure program than a village with a weak signal, and this is significant at $10 \%$. The effects in IV are larger than those in the LPM and logit regressions, which indicates a downward bias in the latter two. One possible explanation for this could be the measurement error of the signal strength variable, which could bias the results.

The 2SLS estimation results for the economic program are presented in columns 
(3) and (4). By instrumenting signal strength with flash rate intensity, the probability of having an economic program increases by 0.6 point in a village with greater signal strength. In column (4), after including the control variables, the results exhibit a lower magnitude than those in column 3 . Nevertheless, they are still statistically significant at $10 \%$ level. Similarly, the magnitude for the economic program in the 2SLS estimation is higher than in the LPM and logit models. Regarding civic engagement, higher signal strength is associated with a higher probability of having civic engagement activities. The results are substantially larger than those that I obtained in Table 4, which could be explained by the fact that areas with more mobile phones tend to have less social participation activities. Another possibility is that the measurement error from the signal strength could yield a downward bias result.

To determine whether the exclusion restriction holds, I estimated the correspondence between flash rate and the dependent variables. Table 6 reveals that flash rate intensity does not have any impact on the dependent variables, conditional on several unobservable village characteristics and all of the control variables.

These three results from the 2SLS estimation method support the evidence obtained from the LPM, logit and matching methods. Therefore, based on the IV estimations, it can be argued that signal strength has causal effects on infrastructure and economic programs in Indonesia. Furthermore, it is also possible to verify that stronger mobile phone signal has a causal relationship with social participation programs in Indonesia. These results are consistent with those obtained by Manacorda and Tesei (2017), who has found that flash rate intensity affects political mobilisation due to its impact on mobile phone adoption.

\subsection{Propensity Score Matching}

To address the selection issues, I constructed a propensity score matching estimator, following Rosenbaum and Rubin (1983) and Abadie and Imbens $(2006,2011) .{ }^{18} \mathrm{~A}$ matching estimator can be used to estimate treatment effects for non-experimental data. This method measures the differences in the outcome variable between the treatment

\footnotetext{
${ }^{18}$ See Abadie et al. (2004) for the practical steps on the implementation of this estimator.
} 
and control groups with the same probability of being treated. This model examines the probability of the outcome variable being $1\left(\operatorname{Pr}\left(Y_{v, t}=1\right)\right)$ for villages with either a strong signal $\left(\right.$ Signal $\left._{v, t}=1\right)$ or a weak signal $\left(\right.$ Signal $\left._{v, t}=0\right)$, but which have an identical probability of having a strong signal based on their observable variables. This method is important because it can minimise the issue with the non-random assignment of signal strength.

This method has two conditions that need to be met to estimates the average treatment effect:

1. Unconfoundedness: $\left(Y_{v, t}=0, Y_{v, t}=1\right) \perp$ Signal $_{v, t} \mid P\left(X_{v, t}^{\prime}, \theta_{v, t}\right)$

2. (Weak) overlap or common support condition: $P\left(X_{v, t}^{\prime}, \theta_{v, t}\right)<1$

where $P\left(X_{v, t}^{\prime}, \theta_{v, t}\right)$ is the probability of receiving treatment or the propensity score of having a strong signal, conditional on the control variables and the village dummies. ${ }^{19}$

In this estimation, I use the matching method based on the same geographic area, because geographically matched controls significantly reduce the possibility of selection bias (Heckman et al., 1998). The set of geographical controls are village topography (1 = the top of the mountain, 2 = valley or slopes, 3 =lowland), paved road, land, distance to sub district and urban dummies. I also include the same control variables that are used in the LPM and Logistic estimation methods.

The matching results are presented in Table 7, where I use the propensity score matching algorithm to compare the differences in outcome variables between villages with higher signal strength (treatment group) and villages with lower signal strength (control group) based on the distance between several covariates. All the results in Table 7 are the estimated average treatment effect (ATE) of signal strength. I use the matching estimations based on the same controls used in previous estimations, and also based on geographical characteristics, such as topography, urban dummy, paved road, land and distance to sub-district. Moreover, I also include the same controls used in equation 1.

The dependent variable in column 1 is infrastructure program. According to the

\footnotetext{
${ }^{19}$ See Rosenbaum and Rubin (1983) for a more comprehensive explanation of the assumptions for a matching method.
} 
results, infrastructure programs are more likely to be implemented in villages with higher signal strength than in villages with weak signal; This result is statistically significant at the $10 \%$ level. For the economic program, the results indicate that villages with high signal strength are more likely to have an economic program than a village with low signal strength. The coefficient is robust and significant at the $1 \%$ level. With regard to civic engagement activity, the results of the nearest neighbour matching estimations indicate that higher signal strength is associated with higher probability of civic engagement activities.

The results from the matching methods confirm and support the previous results from the LPM and Probit method for all independent variables used in this study. This finding is important, because after estimating the differences in the conditional expectation of the dependent variable between villages with higher and lower signal strength that are matched based on their geographical similarities, the results are still similar to and consistent with previous methods. Figure 8 demonstrates the common support condition, and it appears to satisfy the common support condition.

\subsection{Extensions}

Desa versus Kelurahan In the previous section, I discussed the differences between Desa and Kelurahan in terms of administrative characteristics. In this section, I further differentiate the sample into two groups: Desa village and Kelurahan village. Table 8 presents the results of this analysis.

Columns 1 and 2 in Table 8 are the estimation results for Desa. Moreover, columns 3 and 4 are for Kelurahan. I include sub-districts fixed effects instead of village fixed effects to discover whether desa and kelurahan, which are located within the same subdistrict, would provide difference results due to the difference in signal strength. For infrastructure program in Desa, the results from both the LPM and 2SLS models indicate that villages with higher signals are more likely to have infrastructure programs, and this finding is significant at $10 \%$. However, the results for Kelurahan are statistically insignificant for both estimation methods. This result is consistent with the fact that village leaders in Desa have more power, in terms of implementing policies, than village 
leaders in Kelurahan. Therefore, they can be more responsive to any reports or requests made by the villagers.

With regard to the economic program, mobile phone signal is positively associated with the implementation of training or providing grants for those who want to start a new business, but only in the LPM estimation. Moreover, the results for Kelurahan are insignificant for both LPM and 2SLS. This is consistent with the previous finding that villages with better mobile phone signal are more likely to have economic empowerment programs.

For collective action, the results are relatively similar: For desa, mobile phone signal has a positive correlation to civic engagement activities, although it is not significant for the LPM method. Moreover, the results from kelurahan indicate that mobile phone usage has a positive and significant relationship with civic engagement.

In summary, there is a clear difference between desa and kelurahan in terms of the association between mobile phone signal and the outcome variables. The evidence also reveals that village leaders in desa are more responsive with these programs, especially for leaders with more years of education. For kelurahan, however, there is not enough evidence on the relationship between these variables, except for civic engagement activity. This could be explained by the fact that in desa, due to its rural characteristics and lack of facilities, major improvement in infrastructure and economic programs are essential.

Moreover, the village leader in desa has relatively more power and, thus, ability to implement policies than those the leader of kelurahan. Another possible explanation for why a village may be impacted to a greater extent, is due to the fact that they do not have many alternative options to call their leader. Once they have access to better mobile phone signal strength, it is easier for them to request assistance from their leaders. Nevertheless, the distinct differences, in terms of the number of observations, might affect the results presented in this table.

Robustness Check I also performed a robustness check by introducing ordered signal strength as an alternative explanatory variable. This variable has a value of 2 if the 
signal strength is strong, 1 if the signal strength is weak and 0 if there is no signal. Table 9 presents the results for this new variable. Based on the table, the correspondence of ordered signal strength and outcome variables is still statistically significant for all outcome variables (except the LPM result for economic program in column (3)). The results from the 2SLS estimations in columns (2), (4) and (6) also suggest that flash rate intensity has a negative association with ordered signal. The results are statistically significant at $10 \%$ for infrastructure and economic programs, and significant at $1 \%$ for civic engagement.

I also estimate whether the association between signal strength and the dependent variables is driven by signal strength. Table 10 exhibits the results for this estimation. The LPM model was used to test this query. For the infrastructure program, a strong signal appears to be the most important driver. Indeed, strong signal has a positive and significant effect on the likelihood of having an infrastructure program. Similar results can be found in columns (3) and (4): a strong signal has a positive and statistically significant relation to economic program. The results for civic engagement activity, presented in columns (5) and (6), suggest that weak signal strength reduces the likelihood of having civic engagement activities. This is consistent with my prior where mobile phones help villagers communicate and help the village head announce upcoming social participation activities.

\section{Mechanisms}

As explained in Section 4, I propose two mechanisms to explain what drives the extent to which mobile phone affect policies. The first mechanism reveals that better signal strength increases villagers' incentive to report or request their needs to village head. This could be through calling the village head or sending text messages. Therefore, I assume that when villages have better signal strength, it will result in an increase in villagers' consumption of telecommunication services (e.g. due to higher telecommunication bills or top-up mobile phone credits).

The present study uses data from the Indonesian Family Life Survey (IFLS) - a longitudinal survey in Indonesia that represents around 83\% of the Indonesian population 
- and from the household survey from IFLS 4 and IFLS 5, which were conducted in 2007 and 2014, respectively, to determine the amount of money all households spent, in total, for their telecommunication needs in the past month. Table 11 depicts the results for the effect of signal strength on telecommunication expenditures. In columns (1) and (2), sub-district fixed effects were used, and in columns (3) and (4), household fixed effects were used. Control variables were used in columns (2) and (4). The explanatory variable here is the average signal strength in the sub-districts where the households are located.

The results from Table 11 indicate that households living in areas with higher signal strength spend more on telecommunication services. The results are positive and statistically significant for all different estimation methods. This result confirms that when villages have stronger coverage, people are incentivised to use mobile phones more than those who live in areas with weak coverage. In terms of the magnitude, a one standard deviation increase in signal strength is associated with an increase in telecommunication expenditure by 8.9 percentage points in column (2). Moreover, once household fixed effects are controlled for, the magnitude becomes 25.5 percentage points. Therefore, we can also expect that people living in areas with better signal will also be more likely to interact with their village leaders, and thus affect policy.

The second proposed mechanism considers spillover effects. Neighbouring villages with better signal strength will affect other village leaders' policies through the exchange of information between villages. Therefore, when neighbouring villages have good signal strength, other villages will learn about policy that is being implemented by neighbouring village leaders. If a neighbouring village's head performs better, then the people in the village will increase the pressure on their own leader to do the same.

Table 12 provides the results for this mechanism. I use the average signal strength of the neighbouring villages within the same sub-districts as the explanatory variable. All estimation methods use village and year fixed effects. In columns (1) and (2), a one standard deviation increase in neighbouring signal strength is associated with an increase in the likelihood of having an infrastructure program by $1.8 \%$, and it is statistically significant at $1 \%$. Neighbouring signal strength is also positively associated 
with the likelihood of having economic programs, and it is statistically significant at $1 \%$. In columns (3) and (4), it is clear that the point estimates for neighbour signal strength are approximately $5.8 \%$ and $5.5 \%$, respectively. In terms of magnitude, a one standard deviation increase in neighbouring signal strength is associated with an increase in the likelihood of economic programs being implemented by $1.10 \%$. Finally, the estimation results in columns (5) and (6) also suggest that neighbour signal strength is associated with civic engagement activity. A one standard deviation increase in signal strength in the neighbouring village increases the likelihood of civic engagement by $1.54 \%$ to $1.9 \%$, and it is significant at $1 \%$.

\section{Conclusions}

This study explores the village-level data from three waves of Indonesia's village census to investigate the role of mobile phones in policymaking. This study finds that increased signal strength is associated with higher infrastructure and economic programs. Furthermore, mobile phones are very important to mobilise people to do gotong royong or to participate in collective action activities. The results are robust after implementing various estimation strategies. Indeed, the propensity score matching method was used to investigate the average treatment effects between villages with higher and weaker signal strengths. Given the availability of the data, I was able to match the data based on geographical similarities, and thus find a causal relationship between signal strength and policies. The PSM estimation results confirm the results from the LPM and Probit methods.

To acknowledge the potential bias caused by several endogeneity problems, I performed instrumental variable estimations, using lightning strike intensity as the instrument for assessing signal strength. The results from the 2SLS support the results from the LPM and logit estimation methods, even though the 2SLS results yield a higher magnitude and lower statistical significance compared to the other methods. Nevertheless, the results from the 2SLS reveal that mobile phone signal strength has a causal relationship with a village leader's policies, as well as social participation activity. 
In terms of magnitude, this study finds that villages with a strong signal are more likely to have infrastructure programs by 0.37 points, compared with villages with poor signal coverage. Moreover, signal strength is positively associated with economic programs. A strong signal increases the probability that the village head will implement an economic program by 0.52 points. These results suggest that mobile phones could be an effective media for villagers to report or request their needs, especially with regard to infrastructure and the economic sector. It is also because mobile phones increase villagers' incentive to interact with their leader (Grossman et al., 2016, 2014). Moreover, in accordance with previous studies that have found the mobile phones are influential for mobilising people, this study reveals that signal strength increases civic engagement activity by 1.59 points. Thus, this study confirms that mobile phones could help village heads inform people about collective action activity and upcoming social activity.

I also extended the analysis by splitting the sample into rural villages (desa) and urban villages (kelurahan). The results indicate that there is a heterogeneous effect between urban and rural villages, especially for programs related to infrastructure and economic empowerment. The results for kelurahan are statistically insignificant. This is likely because there is a significant difference in terms of the government characteristics between urban and rural villages. Whereas village leaders in kelurahan are appointed by the district government, and most of them are civil servants, village leaders in desa are elected through village elections and have greater power than village leaders in kelurahan. For civic engagement activity, this study finds no significant difference between rural and urban villages. Indeed, for both, signal strength increases the likelihood of having social participation activities.

These findings could be useful to enhance the role of mobile phones in policymaking throughout the world. Some policy recommendations for Indonesia would be to increase access to ICT infrastructure in the country by expanding ICT availability, especially in the remote areas. This can also be implemented in other countries, as many areas throughout the world still lack investment in ICT infrastructure.

Nevertheless, there are several limitations of this study. First, this study does 
not consider the political power of the village leader (e.g. vote share for the village leader and political alignment). Using alternative ICT data could probably enhance the robustness of the results; for example, data on ICTs before the expansion of ICT infrastructure in Indonesia. Aggregating data to the district level could also help explain the impact of mobile phones on district governments, since these governments have a greater responsibility to provide service delivery.

A future study could also expand this analysis to include the role of media on the effectiveness of leaders' policies on service delivery. Finally, extending the presence of digital media (e.g. smart phones, tablets and government monitoring Apps) or social media (e.g. Twitter and Facebook) could also be an interesting topic for future work. 


\section{References}

Abadie, A., Drukker, D., Herr, J. L., Imbens, G. W., et al. (2004). Implementing matching estimators for average treatment effects in stata. Stata journal, 4:290-311.

Abadie, A. and Imbens, G. W. (2006). Large sample properties of matching estimators for average treatment effects. Econometrica, 74(1):235-267.

Abadie, A. and Imbens, G. W. (2011). Bias-corrected matching estimators for average treatment effects. Journal of Business \& Economic Statistics, 29(1):1-11.

Abadie, A. and Imbens, G. W. (2016). Matching on the estimated propensity score. Econometrica, 84(2):781-807.

Ahn, H. and Lee, M.-H. (1999). An econometric analysis of the demand for access to mobile telephone networks. Information Economics and Policy, 11(3):297-305.

Aker, J. C. (2010). Information from markets near and far: Mobile phones and agricultural markets in Niger. American Economic Journal: Applied Economics, 2(3):46-59.

Aker, J. C., Collier, P., and Vicente, P. C. (2017). Is information power? using mobile phones and free newspapers during an election in Mozambique. Review of Economics and Statistics.

Aker, J. C. and Fafchamps, M. (2014). Mobile phone coverage and producer markets: Evidence from West Africa. The World Bank Economic Review, 29(2):262-292.

Aker, J. C. and Mbiti, I. M. (2010). Mobile phones and economic development in Africa. The Journal of Economic Perspectives, 24(3):207-232.

Albrecht, R., Goodman, S., Petersen, W., Buechler, D., Bruning, E., Blakeslee, R., and Christian, H. (2011). The 13 years of trmm lightning imaging sensor: from individual flash characteristics to decadal tendencies.

Andersen, T. B., Bentzen, J., Dalgaard, C.-J., and Selaya, P. (2012). Lightning, it diffusion, and economic growth across us states. Review of Economics and Statistics, 94(4):903-924. 
Angrist, J. and Krueger, A. (2001). Instrumental variables and the search for identification: from supply and demand to natural experiments. Journal of Economics Perspectives, 15(4):69-85.

Angrist, J. D. and Pischke, J. (2009). Mostly Harmless Econometrics: An Empiricist Companion. Princeton University Press, Princeton.

Antlöv, H. (2003). Village government and rural development in Indonesia: The new democratic framework. Bulletin of Indonesian Economic Studies, 39(2):193-214.

Antlöv, H., Wetterberg, A., and Dharmawan, L. (2016). Village governance, community life, and the 2014 village law in Indonesia. Bulletin of Indonesian Economic Studies, 52(2):161-183.

Athey, S. and Imbens, G. W. (2017). The state of applied econometrics: Causality and policy evaluation. Journal of Economic Perspectives, 31(2):3-32.

Bailard, C. S. (2009). Mobile phone diffusion and corruption in africa. Political Communication, 26(3):333-353.

Baulch, E. (2017). Mobile phones: advertising, consumerism and class. In Jurriëns, E. and Tapsell, R., editors, Digital Indonesia: Connectivity and Divergence. ISEAS-Yusof Ishak Institute.

Bebbington, A., Dharmawan, L., Fahmi, E., and Guggenheim, S. (2006). Local capacity, village governance, and the political economy of rural development in Indonesia. World Development, 34(11):1958-1976.

Berelson, B. (1954). Voting: A study of opinion formation in a presidential campaign. University of Chicago Press.

Besley, T. and Burgess, R. (2002). The political economy of government responsiveness: Theory and evidence from India. The Quarterly Journal of Economics, 117(4):1415-1451.

Bowen, J. R. (1986). On the political construction of tradition: Gotong royong in Indonesia. The Journal of Asian Studies, 45(3):545-561. 
Buys, P., Dasgupta, S., Thomas, T. S., and Wheeler, D. (2009). Determinants of a digital divide in sub-saharan africa: A spatial econometric analysis of cell phone coverage. World Development, 37(9):1494-1505.

Cecil, D. J., Buechler, D. E., and Blakeslee, R. J. (2014). Gridded lightning climatology from trmm-lis and otd: Dataset description. Atmospheric Research, 135:404-414.

Central Bureau of Statistics (2014). Indonesia village cencus/Potensi Desa.

Cook, F. L., Tyler, T. R., Goetz, E. G., Gordon, M. T., Protess, D., Leff, D. R., and Molotch, H. L. (1983). Media and agenda setting: Effects on the public, interest group leaders, policy makers, and policy. Public Opinion Quarterly, 47(1):16-35.

DellaVigna, S. and Gentzkow, M. (2010). Persuasion: empirical evidence. Annu. Rev. Econ., 2(1):643-669.

Enikolopov, R. and Petrova, M. (2016). Media capture: empirical evidence. Handbook of media economics. Amsterdam: Elsevier.

Enikolopov, R., Petrova, M., and Zhuravskaya, E. (2011). Media and political persuasion: Evidence from Russia. The American Economic Review, 101(7):3253-3285.

Evers, P. J. (2000). Resourceful villagers, powerless communities: Rural village government in Indonesia. mimeo, Jakarta, World Bank.

Gentzkow, M., Shapiro, J. M., and Sinkinson, M. (2011). The effect of newspaper entry and exit on electoral politics. The American Economic Review, 101(7):2980-3018.

Greene, W. (2004). The behaviour of the maximum likelihood estimator of limited dependent variable models in the presence of fixed effects. The Econometrics Journal, 7(1):98-119.

Grossman, G., Humphreys, M., and Sacramone-Lutz, G. (2014). "i wld like u wmp to extend electricity 2 our village": On information technology and interest articulation. American Political Science Review, 108(3):688-705. 
Grossman, G., Michelitch, K., and Santamaria, M. (2016). Texting complaints to politicians: Name personalization and politicians' encouragement in citizen mobilization. Comparative Political Studies, page 0010414016666862.

Gruber, H. and Verboven, F. (2001). The diffusion of mobile telecommunications services in the European Union. European Economic Review, 45(3):577-588.

Heckman, J., Ichimura, H., Smith, J., and Todd, P. (1998). Characterizing selection bias using experimental data. Econometrica, 66(5):1017-1098.

Heckman, J. J. (1979). Sample selection bias as a specification error. Econometrica, 47(1):153-161.

Jensen, R. (2007). The digital provide: Information (technology), market performance, and welfare in the South Indian fisheries sector. The Quarterly Journal of Economics, 122(3):879-924.

Lazarsfeld, P., Berelson, B., and Gaudet, H. (1944). The People's Choice: How the Voter Makes Up His Mind in a Presidential Campaign. Columbia university. Bureau of applied social research. Publication no. B-3. Duell, Sloan and Pearce.

Lee, R. C. and Findlay, C. (2005). Telecommunications reform in Indonesia: Achievements and challenges. Bulletin of Indonesian Economic Studies, 41(3):341-365.

Lewis, B. D. (2015). Decentralising to villages in Indonesia: Money (and other) mistakes. Public Administration and Development, 35(5):347-359.

Manacorda, M. and Tesei, A. (2017). Liberation technology: mobile phones and political mobilisation in Africa. Working paper, Centre for Economic Performance, LSE.

Martinez-Bravo, M. (2014). The role of local officials in new democracies: Evidence from Indonesia. The American Economic Review, 104(4):1244-1287.

Martinez-Bravo, M. (2016). The local political economy effects of school construction in Indonesia. American Economic Journal: Applied Economics.

Ministry of Home Office (2014). Pembentukan daerah-daerah otonom di Indonesia sampai dengan tahun 2014 . 
Minnesota Population Center (2017). Integrated public use microdata series, international: Version 6.5 [dataset]. Minneapolis: University of Minnesota. http : //doi.org/10.18128/D020.V6.5.

Murray, M. P. (2006). Avoiding invalid instruments and coping with weak instruments. Journal of Economic Perspectives, 20(4):111-132.

Olken, B. A. (2009). Do television and radio destroy social capital? evidence from Indonesian villages. American Economic Journal: Applied Economics, 1(4):1-33.

Pierskalla, J. H. and Hollenbach, F. M. (2013). Technology and collective action: The effect of cell phone coverage on political violence in Africa. American Political Science Review, 107(2):207-224.

Prat, A. and Stromberg, D. (2013). The political economy of mass media. In Advances in Economics and Econometrics: Volume 2, Applied Economics: Tenth World Congress, volume 50, page 135. Cambridge University Press.

PT Telekomunikasi Selular (2016). Building Indonesia digital economy, 2016 annual report.

Reinikka, R. and Svensson, J. (2011). The power of information in public services: Evidence from education in Uganda. Journal of Public Economics, 95(7):956-966.

Rohman, I. K. (2014). Review of Indonesian broadband development. Technical report, LIRNEasia.

Rosenbaum, P. R. and Rubin, D. B. (1983). The central role of the propensity score in observational studies for causal effects. Biometrika, 70(1):41-55.

Shapiro, J. N. and Weidmann, N. B. (2015). Is the phone mightier than the sword? cellphones and insurgent violence in Iraq. International Organization, 69(2):247-274.

Snyder Jr, J. M. and Strömberg, D. (2010). Press coverage and political accountability. Journal of Political Economy, 118(2):355-408.

Staiger, D. and Stock, J. H. (1997). Instrumental variables regression with weak instruments. Econometrica, 65:557-586. 
Strömberg, D. (2001). Mass media and public policy. European Economic Review, 45(4):652-663.

Strömberg, D. (2004a). Mass media competition, political competition, and public policy. The Review of Economic Studies, 71(1):265-284.

Strömberg, D. (2004b). Radio's impact on public spending. The Quarterly Journal of Economics, 119(1):189-221.

Strömberg, D. (2015). Media and politics. Annual Review of Economics, 7(1):173-205.

Strömberg, D. (2016). Media coverage and political accountability: Theory and evidence. Handbook of Media Economics. Amsterdam: Elsevier.

The World Bank (2016). World development report 2016: Digital dividends.

Wooldridge, J. M. (2010). Econometric analysis of cross section and panel data. MIT press. 


\section{Figures and Tables}

Figure 1: The Development of ICTs Subscription in Indonesia (in 10,000 People)

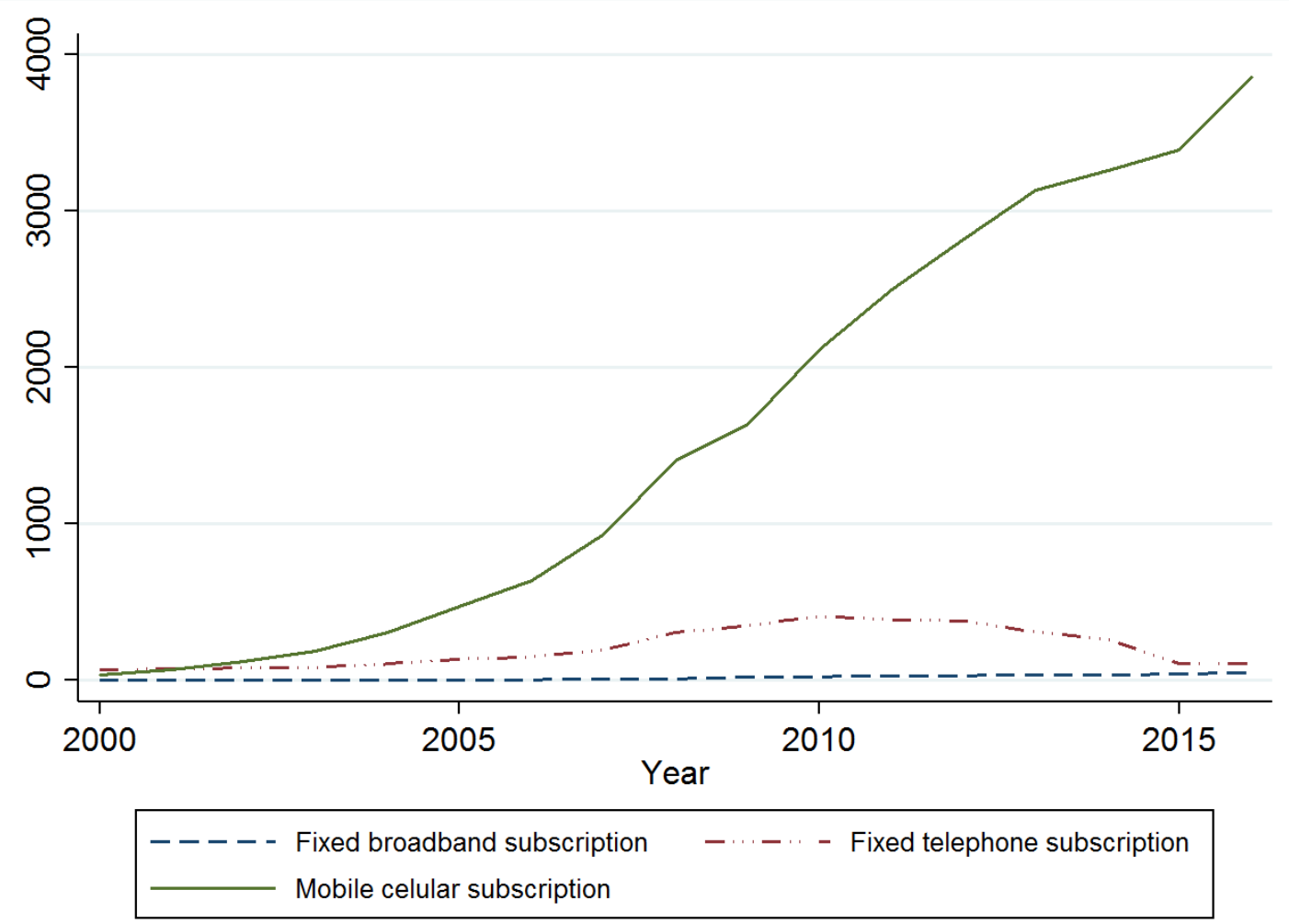

Source: ITU, 2017 
Figure 2: Mobile Phone Subscriptions at District Level in 2010

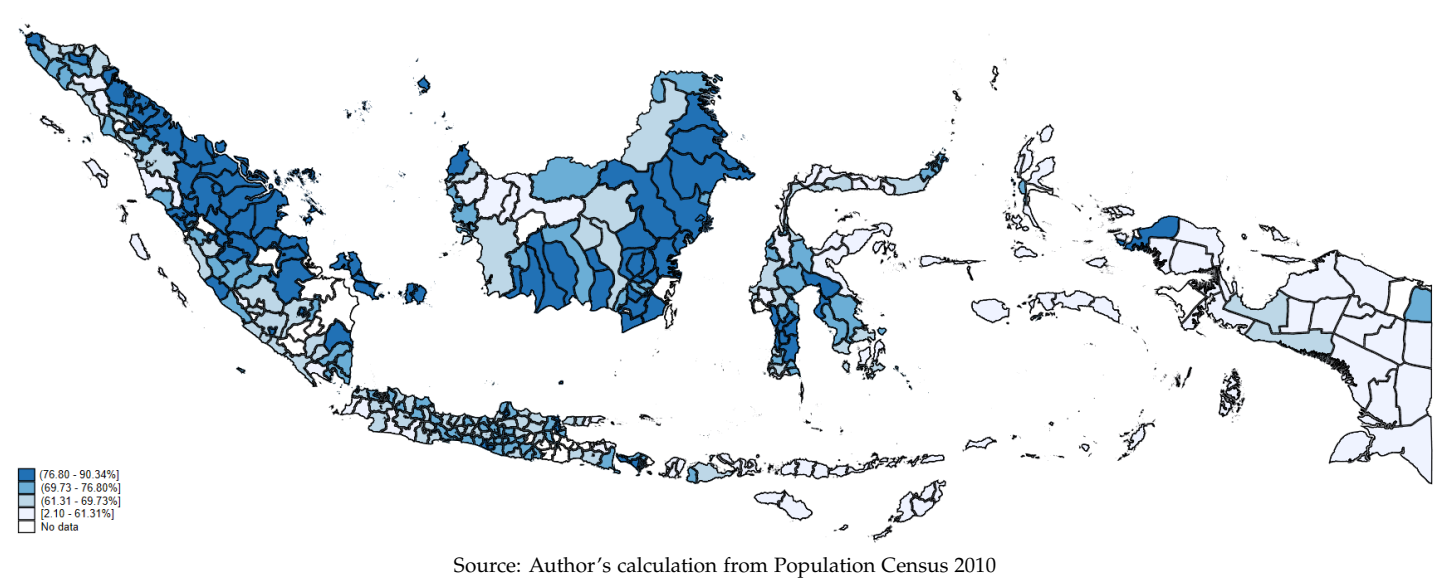

Figure 3: Mobile Phone Subscriptions at District Level in 2005

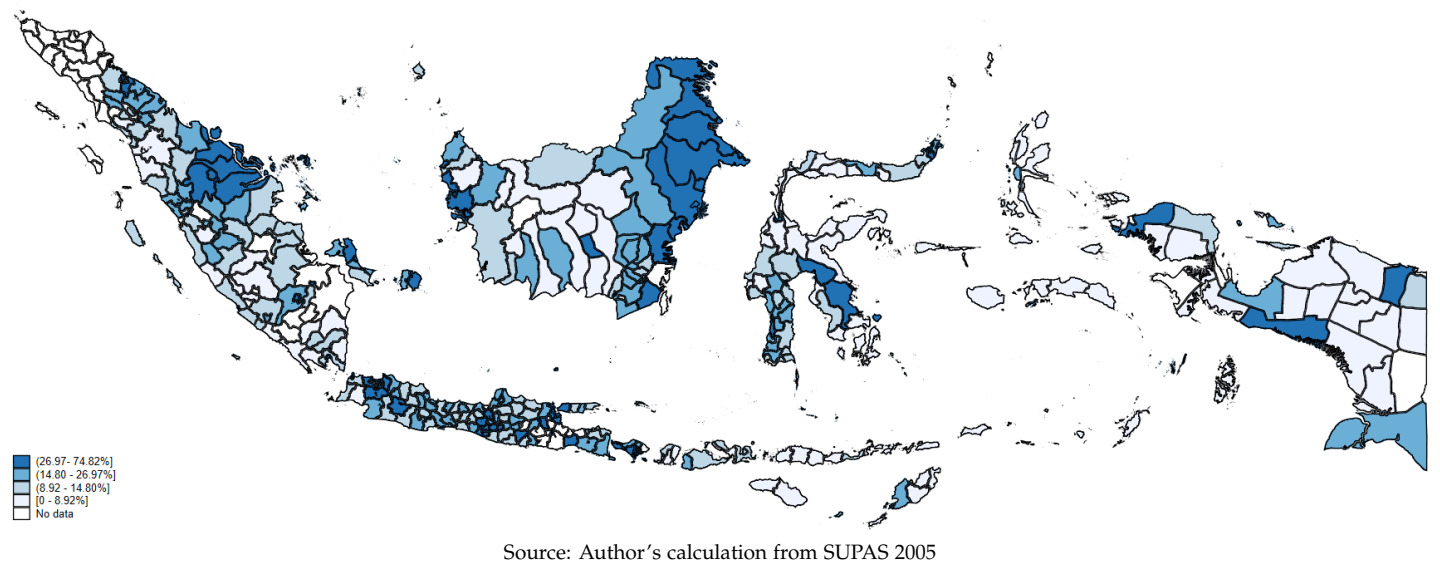


Figure 4: Mobile Phone Signal Strength at Village Level in 2014

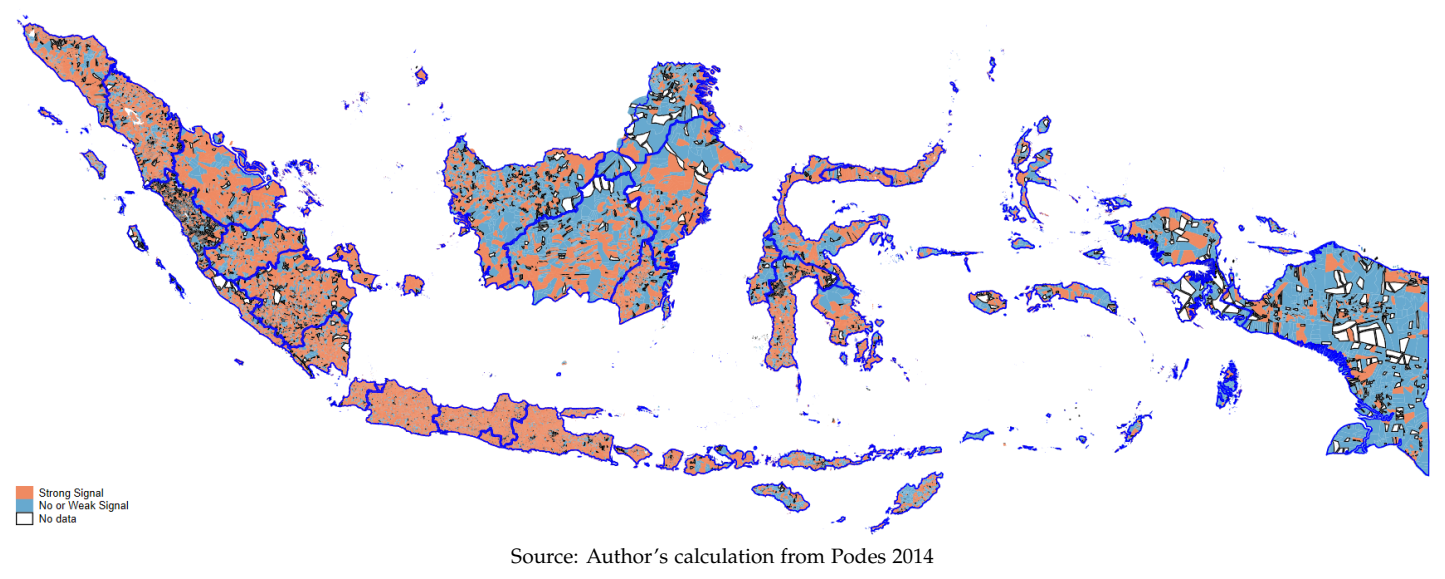

Figure 5: Mobile Phone Signal Strength at Village Level in 2011

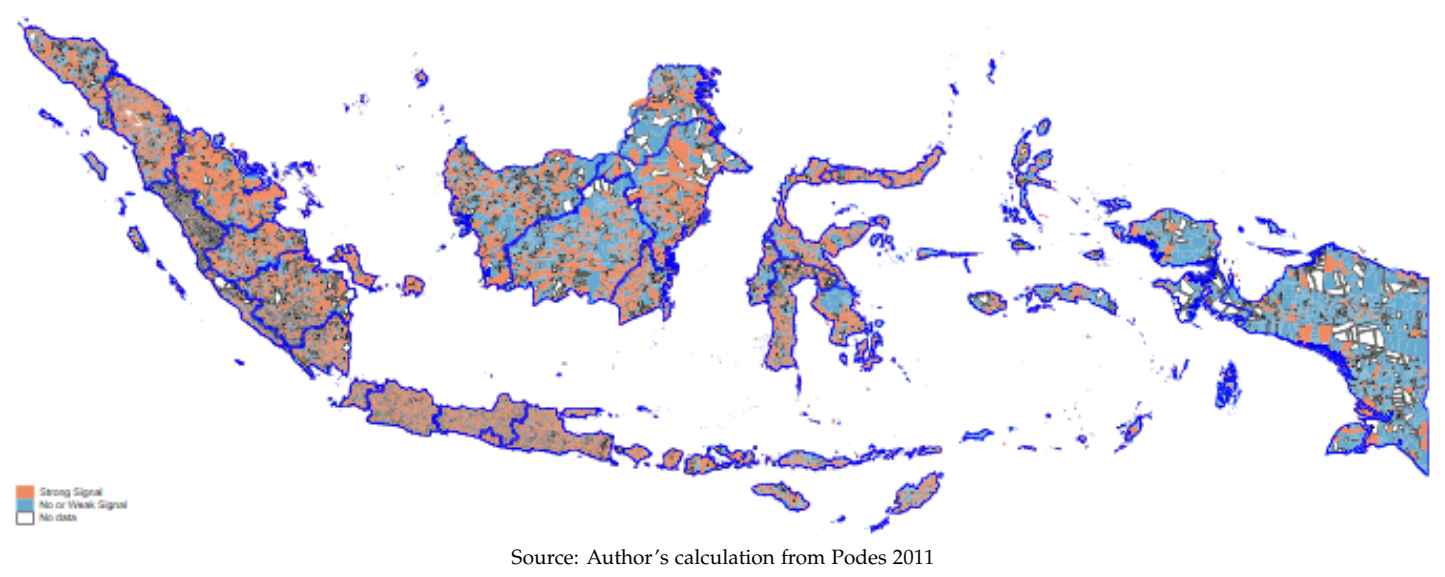

Figure 6: Mobile Phone Signal Strength at Village Level in 2008

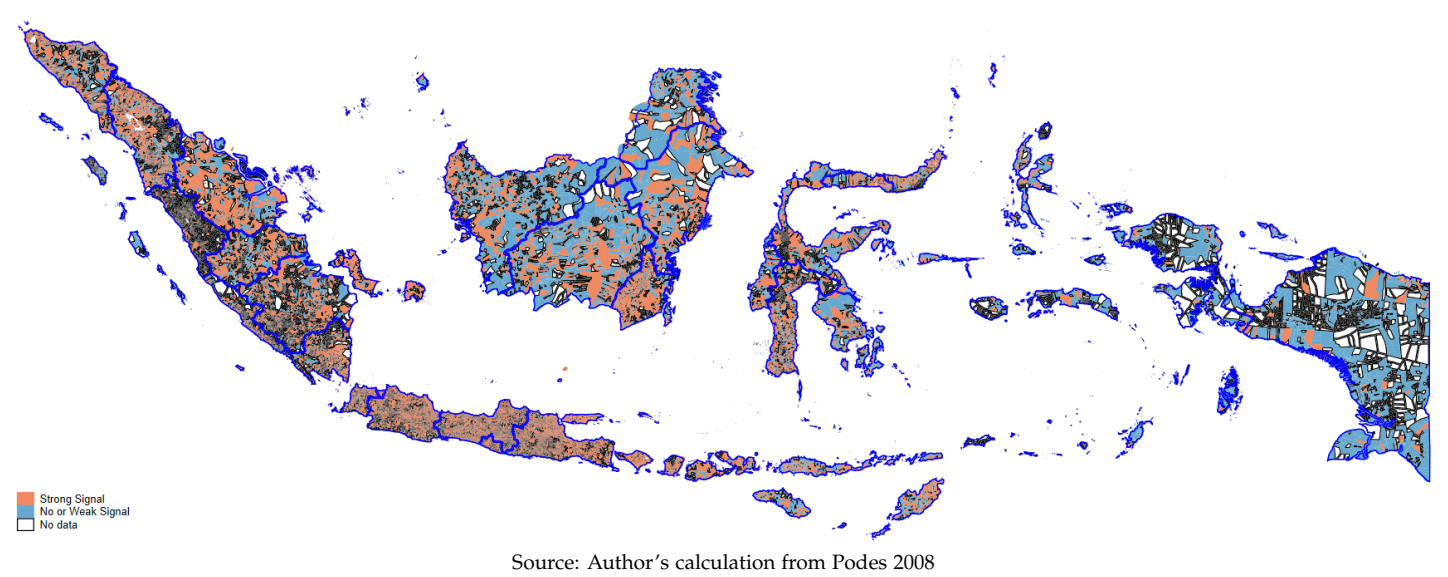


Figure 7: Mean Annual Flash Rate Density between 1998 and 2013 (Flash Rate/ km²)

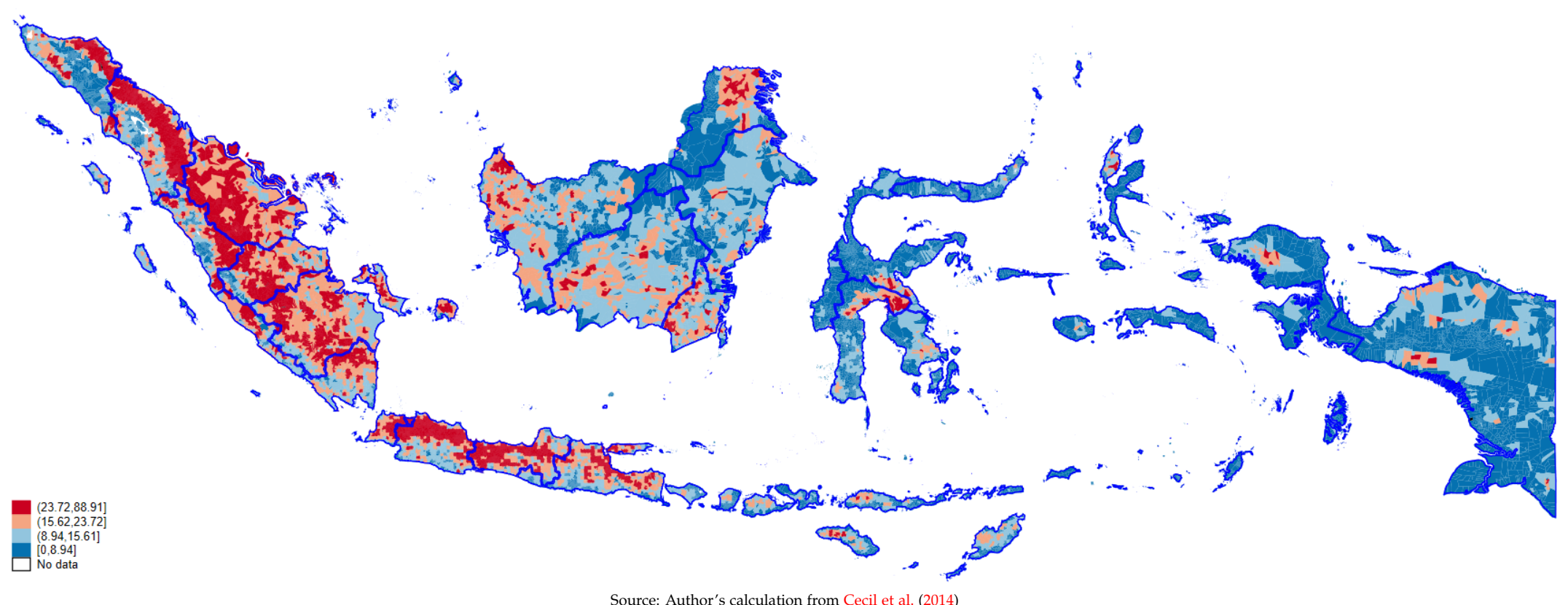

Source: Author's calculation from Cecil et al. (2014) 
Table 1: Summary Statistics

\begin{tabular}{|c|c|c|c|c|c|}
\hline Variable & Obs & Mean & Std. Dev. & Min & Max \\
\hline \multicolumn{6}{|l|}{ Main Variables } \\
\hline $\begin{array}{l}\text { Infrastructure } \\
=1 \text { if there is program for infrastructure; } 0=\text { otherwise }\end{array}$ & 42,663 & 0.55 & 0.50 & 0 & 1 \\
\hline $\begin{array}{l}\text { Economic } \\
=1 \text { if there is program on providing capital; } 0=\text { otherwise }\end{array}$ & 42,663 & 0.53 & 0.49 & 0 & 1 \\
\hline $\begin{array}{l}\text { Civic Engagement } \\
=1 \text { if village has civic engagement activity; } 0=\text { otherwise }\end{array}$ & 42,663 & 0.47 & 0.49 & 0 & 1 \\
\hline $\begin{array}{l}\text { Signal } \\
=1 \text { if signal is very strong; } 0=\text { otherwise }\end{array}$ & 42,663 & 0.81 & 0.39 & 0 & 1 \\
\hline $\begin{array}{l}\text { Base Transceiver Station } \\
=1 \text { if village has BTS; } 0=\text { otherwise }\end{array}$ & 42,663 & 0.37 & 0.48 & 0 & 1 \\
\hline Mean flash rate density (flash rate $/ \mathrm{km}^{2}$ ) & 42,663 & 20.29 & 10.91 & 0 & 88.91 \\
\hline \multicolumn{6}{|l|}{ Other Variables } \\
\hline $\begin{array}{l}\text { Female Leader } \\
\text { Age } \\
\text { Years of Education } \\
\text { Population (in numbers of people) } \\
\text { Expenditure per Capita (in Rupiah) } \\
\text { Main Source of Income } \\
1 \text { = agriculture; } 0 \text { = others }\end{array}$ & \begin{tabular}{l|}
41,594 \\
41,594 \\
41,594 \\
42,663 \\
42,663 \\
42,663
\end{tabular} & $\begin{array}{c}0.06 \\
44.59 \\
12.35 \\
4,229.78 \\
520,427.8 \\
0.84\end{array}$ & $\begin{array}{c}0.24 \\
8.13 \\
2.66 \\
4,598.85 \\
231,317.1 \\
0.36\end{array}$ & $\begin{array}{c}0 \\
20 \\
0 \\
16 \\
179,700 \\
0\end{array}$ & $\begin{array}{c}1 \\
87 \\
22 \\
95,031 \\
2,671,080 \\
1\end{array}$ \\
\hline $\begin{array}{l}\text { Muslim Majority } \\
\text { Multi Ethnic } \\
\text { Numbers of Mosque } \\
\text { Numbers of Church } \\
\text { Topography } \\
1 \text { = Top of a Mountain } \\
2 \text { = Valley or Slopes } \\
3 \text { = Lowland }\end{array}$ & $\begin{array}{l}42,663 \\
42,663 \\
42,663 \\
42,663 \\
42,663\end{array}$ & $\begin{array}{l}0.44 \\
0.65 \\
4.78 \\
0.55 \\
2.68\end{array}$ & $\begin{array}{l}0.49 \\
0.47 \\
5.07 \\
1.63 \\
0.71\end{array}$ & $\begin{array}{l}0 \\
0 \\
0 \\
0 \\
1\end{array}$ & $\begin{array}{c}1 \\
1 \\
99 \\
75 \\
3\end{array}$ \\
\hline Coastal & 42,663 & 0.07 & 0.26 & 0 & 1 \\
\hline $\begin{array}{l}\text { Transportation Access } \\
1=\text { by land, } 0=\text { otherwise }\end{array}$ & 42,663 & 0.96 & 0.20 & 0 & 1 \\
\hline Asphalt Road & 42,663 & 0.75 & 0.43 & 0 & 1 \\
\hline Distance to Jakarta $(\mathrm{km})$ & 42,663 & 705.86 & 560.04 & 10.61 & $3,773.78$ \\
\hline Distance to District $(\mathrm{km})$ & 42,663 & 32.35 & 38.99 & 0.1 & 999.8 \\
\hline Distance to Sub-District $(\mathrm{km})$ & 42,663 & 6.69 & 11.18 & 0.05 & 599.8 \\
\hline Village Own Sources Revenues (in million Rupiah) & 42,663 & 80.54 & 228.94 & 0 & 9,857 \\
\hline \multicolumn{6}{|l|}{ Additional Informations } \\
\hline $\begin{array}{l}\text { Number of Provinces } \\
\text { Number of Districts } \\
\text { Number of Sub-districts }\end{array}$ & $\begin{array}{c}27 \\
156 \\
1188\end{array}$ & & & & \\
\hline
\end{tabular}


Table 2: Baseline Results: Infrastructure Program

\begin{tabular}{|c|c|c|c|c|c|c|}
\hline & (1) & $(2)$ & (3) & (4) & (5) & (6) \\
\hline Signal & $\begin{array}{l}0.054^{* * *} \\
(0.0093)\end{array}$ & $\begin{array}{c}0.011^{*} \\
(0.0066)\end{array}$ & $\begin{array}{c}0.013^{*} \\
(0.0068)\end{array}$ & $\begin{array}{l}0.014^{* *} \\
(0.0068)\end{array}$ & $\begin{array}{l}0.11^{* *} \\
(0.056)\end{array}$ & $\begin{array}{l}0.11^{* * *} \\
(0.035)\end{array}$ \\
\hline Male Leader & & & $\begin{array}{l}-0.0089 \\
(0.010)\end{array}$ & $\begin{array}{l}-0.012 \\
(0.010)\end{array}$ & $\begin{array}{l}-0.038 \\
(0.085)\end{array}$ & $\begin{array}{l}-0.090^{*} \\
(0.054)\end{array}$ \\
\hline Age & & & $\begin{array}{c}0.00073^{* *} \\
(0.00033)\end{array}$ & $\begin{array}{c}0.00084^{* *} \\
(0.00033)\end{array}$ & $\begin{array}{c}0.0065^{* *} \\
(0.0026)\end{array}$ & $\begin{array}{c}0.0091^{* * *} \\
(0.0016)\end{array}$ \\
\hline Years of Education & & & $\begin{array}{c}0.0037^{* * *} \\
(0.0010)\end{array}$ & $\begin{array}{c}0.0039^{* * *} \\
(0.0010)\end{array}$ & $\begin{array}{l}0.022^{* * *} \\
(0.0083)\end{array}$ & $\begin{array}{l}0.025^{* * *} \\
(0.0052)\end{array}$ \\
\hline Log Population & & & $\begin{array}{c}-0.060^{* * *} \\
(0.0092)\end{array}$ & $\begin{array}{c}-0.052^{* * *} \\
(0.0091)\end{array}$ & $\begin{array}{l}-0.21 \\
(0.13)\end{array}$ & $\begin{array}{l}0.32^{* * *} \\
(0.019)\end{array}$ \\
\hline Log Expenditure per Capita & & & $\begin{array}{c}-0.088^{* * *} \\
(0.018)\end{array}$ & $\begin{array}{c}-0.092^{* * *} \\
(0.018)\end{array}$ & $\begin{array}{c}-0.48^{* * *} \\
(0.18)\end{array}$ & $\begin{array}{c}-0.20^{* * *} \\
(0.057)\end{array}$ \\
\hline Main Sources of Income & & & $\begin{array}{c}0.013 \\
(0.013)\end{array}$ & $\begin{array}{l}0.0089 \\
(0.013)\end{array}$ & $\begin{array}{l}-0.089 \\
(0.11)\end{array}$ & $\begin{array}{c}0.021 \\
(0.046)\end{array}$ \\
\hline Muslim & & & $\begin{array}{c}-0.028^{* * *} \\
(0.0081)\end{array}$ & $\begin{array}{c}-0.024^{* * *} \\
(0.0082)\end{array}$ & $\begin{array}{c}-0.21^{* * *} \\
(0.063)\end{array}$ & $\begin{array}{c}-0.23^{* * *} \\
(0.043)\end{array}$ \\
\hline Multi Ethnic & & & $\begin{array}{l}-0.014^{* *} \\
(0.0057)\end{array}$ & $\begin{array}{l}-0.0066 \\
(0.0057)\end{array}$ & $\begin{array}{l}-0.055 \\
(0.046)\end{array}$ & $\begin{array}{c}-0.080^{* * *} \\
(0.029)\end{array}$ \\
\hline Mosque & & & $\begin{array}{c}0.0012 \\
(0.00084)\end{array}$ & $\begin{array}{c}0.0014^{*} \\
(0.00084)\end{array}$ & $\begin{array}{l}0.0098^{*} \\
(0.0059)\end{array}$ & $\begin{array}{l}0.030^{* * *} \\
(0.0032)\end{array}$ \\
\hline Church & & & $\begin{array}{l}-0.0016 \\
(0.0021)\end{array}$ & $\begin{array}{l}-0.0012 \\
(0.0021)\end{array}$ & $\begin{array}{c}0.00074 \\
(0.018)\end{array}$ & $\begin{array}{c}-0.079^{* * *} \\
(0.0091)\end{array}$ \\
\hline$N$ & 42663 & 42663 & 41594 & 41594 & 34768 & 41594 \\
\hline $\begin{array}{l}R^{2} \\
\text { pseudo } R^{2}\end{array}$ & 0.001 & 0.472 & 0.467 & 0.470 & 0.617 & \\
\hline Estimation Method & LPM & LPM & LPM & LPM & Logit & Logit \\
\hline Village FE & Yes & Yes & Yes & Yes & Yes & No \\
\hline Year FE & No & Yes & Yes & Yes & Yes & Yes \\
\hline Urban * Year FE & No & No & No & Yes & Yes & Yes \\
\hline
\end{tabular}

${ }^{*}$ Notes: Robust standard errors in parentheses. Columns (1) - (4) are at the village levels. The unit of observation is at the village level. The dependent variable in this estimation is dummy variable for infrastructure program at the village level. The years included in the regressions are 2008, 2011 and 2014. Column (5) is the coefficient for the fixed effects logit regression. Column (6) is the coefficient for the random effects logit regression. ${ }^{*} p<0.10,{ }^{* *} p<0.05,{ }^{* * *}$ $p<0.01$ 
Table 3: Baseline Results: Economic Program

\begin{tabular}{|c|c|c|c|c|c|c|}
\hline & (1) & (2) & (3) & (4) & (5) & (6) \\
\hline Signal & $\begin{array}{l}0.050^{* * *} \\
(0.0087)\end{array}$ & $\begin{array}{l}0.017^{* *} \\
(0.0076)\end{array}$ & $\begin{array}{l}0.016^{* *} \\
(0.0078)\end{array}$ & $\begin{array}{l}0.017^{* *} \\
(0.0078)\end{array}$ & $\begin{array}{c}0.098^{* *} \\
(0.044)\end{array}$ & $\begin{array}{l}0.15^{* * *} \\
(0.031)\end{array}$ \\
\hline Male Leader & & & $\begin{array}{l}0.0015 \\
(0.012)\end{array}$ & $\begin{array}{l}0.0011 \\
(0.012)\end{array}$ & $\begin{array}{l}-0.026 \\
(0.068)\end{array}$ & $\begin{array}{l}-0.078^{*} \\
(0.048)\end{array}$ \\
\hline Age & & & $\begin{array}{c}0.00090^{* *} \\
(0.00037)\end{array}$ & $\begin{array}{c}0.00092^{* *} \\
(0.00037)\end{array}$ & $\begin{array}{l}0.0041^{*} \\
(0.0021)\end{array}$ & $\begin{array}{c}0.0092^{* * *} \\
(0.0015)\end{array}$ \\
\hline Years of Education & & & $\begin{array}{c}0.0049^{* * *} \\
(0.0012)\end{array}$ & $\begin{array}{c}0.0050^{* * *} \\
(0.0012)\end{array}$ & $\begin{array}{c}0.027^{* * *} \\
(0.0067)\end{array}$ & $\begin{array}{l}0.031^{* * *} \\
(0.0047)\end{array}$ \\
\hline Log Population & & & $\begin{array}{c}-0.050^{* * *} \\
(0.013)\end{array}$ & $\begin{array}{c}-0.049^{* * *} \\
(0.013)\end{array}$ & $\begin{array}{c}-0.21^{* * *} \\
(0.079)\end{array}$ & $\begin{array}{l}0.28^{* * *} \\
(0.016)\end{array}$ \\
\hline Log Expenditure per Capita & & & $\begin{array}{c}-0.10^{* * *} \\
(0.022)\end{array}$ & $\begin{array}{c}-0.10^{* * *} \\
(0.022)\end{array}$ & $\begin{array}{c}-0.33^{* *} \\
(0.14)\end{array}$ & $\begin{array}{c}-0.21^{* * *} \\
(0.050)\end{array}$ \\
\hline Main Sources of Income & & & $\begin{array}{l}-0.011 \\
(0.015)\end{array}$ & $\begin{array}{l}-0.011 \\
(0.015)\end{array}$ & $\begin{array}{c}-0.12 \\
(0.085)\end{array}$ & $\begin{array}{c}0.011 \\
(0.042)\end{array}$ \\
\hline Muslim & & & $\begin{array}{l}-0.018^{*} \\
(0.0093)\end{array}$ & $\begin{array}{c}-0.017^{*} \\
(0.0094)\end{array}$ & $\begin{array}{c}-0.15^{* * *} \\
(0.054)\end{array}$ & $\begin{array}{c}-0.25^{* * *} \\
(0.040)\end{array}$ \\
\hline Multi Ethnic & & & $\begin{array}{c}-0.017^{* * *} \\
(0.0065)\end{array}$ & $\begin{array}{l}-0.016^{* *} \\
(0.0066)\end{array}$ & $\begin{array}{c}-0.086^{* *} \\
(0.036)\end{array}$ & $\begin{array}{c}-0.15^{* * *} \\
(0.026)\end{array}$ \\
\hline Mosque & & & $\begin{array}{c}0.00085 \\
(0.00091)\end{array}$ & $\begin{array}{c}0.00089 \\
(0.00091)\end{array}$ & $\begin{array}{c}0.0098^{*} \\
(0.0052)\end{array}$ & $\begin{array}{l}0.034^{* * *} \\
(0.0030)\end{array}$ \\
\hline Church & & & $\begin{array}{c}-0.0048^{*} \\
(0.0025)\end{array}$ & $\begin{array}{c}-0.0047^{*} \\
(0.0025)\end{array}$ & $\begin{array}{l}-0.021 \\
(0.014)\end{array}$ & $\begin{array}{c}-0.086^{* * *} \\
(0.0084)\end{array}$ \\
\hline$N$ & 42663 & 42663 & 41594 & 41594 & 30076 & 41594 \\
\hline$R^{2}$ & 0.001 & 0.212 & 0.213 & 0.213 & & \\
\hline pseudo $R^{2}$ & & & & & 0.285 & \\
\hline Estimation Method & LPM & LPM & LPM & LPM & Logit & Logit \\
\hline Village FE & Yes & Yes & Yes & Yes & Yes & No \\
\hline Year FE & No & Yes & Yes & Yes & Yes & Yes \\
\hline Urban * Year FE & No & No & No & Yes & Yes & Yes \\
\hline
\end{tabular}

* Notes: Robust standard errors in parentheses. Columns (1) - (4) are at the village levels. The unit of observation is at the village level. The dependent variable in this estimation is dummy variable for economic program at the village level. The years included in the regressions are 2008, 2011 and 2014. Column (5) is the coefficient for the fixed effects logit regression. Column (6) is the coefficient for the random effects logit regression. ${ }^{*} p<0.10,{ }^{* *} p<0.05,{ }^{* * *}$ $p<0.01$ 
Table 4: Baseline Results: Civic Engagement

\begin{tabular}{|c|c|c|c|c|c|c|}
\hline & (1) & (2) & (3) & (4) & (5) & (6) \\
\hline Signal & $\begin{array}{l}0.051^{* * *} \\
(0.0079)\end{array}$ & $\begin{array}{l}0.013^{* *} \\
(0.0062)\end{array}$ & $\begin{array}{l}0.018^{* * *} \\
(0.0063)\end{array}$ & $\begin{array}{l}0.019^{* * *} \\
(0.0063)\end{array}$ & $\begin{array}{l}-0.020 \\
(0.080)\end{array}$ & $\begin{array}{l}0.11^{* * *} \\
(0.041)\end{array}$ \\
\hline Male Leader & & & $\begin{array}{l}-0.0036 \\
(0.0092)\end{array}$ & $\begin{array}{l}-0.0047 \\
(0.0092)\end{array}$ & $\begin{array}{l}-0.14 \\
(0.14)\end{array}$ & $\begin{array}{l}-0.035 \\
(0.071)\end{array}$ \\
\hline Age & & & $\begin{array}{l}-0.00035 \\
(0.00030)\end{array}$ & $\begin{array}{l}-0.00029 \\
(0.00030)\end{array}$ & $\begin{array}{l}0.00040 \\
(0.0040)\end{array}$ & $\begin{array}{l}0.0051^{* *} \\
(0.0020)\end{array}$ \\
\hline Years of Education & & & $\begin{array}{c}0.00075 \\
(0.00097)\end{array}$ & $\begin{array}{c}0.00092 \\
(0.00097)\end{array}$ & $\begin{array}{l}-0.012 \\
(0.012)\end{array}$ & $\begin{array}{l}0.015^{* *} \\
(0.0061)\end{array}$ \\
\hline Log Population & & & $\begin{array}{c}-0.010 \\
(0.0099)\end{array}$ & $\begin{array}{l}-0.0067 \\
(0.0099)\end{array}$ & $\begin{array}{l}-0.15 \\
(0.17)\end{array}$ & $\begin{array}{l}0.33^{* * *} \\
(0.022)\end{array}$ \\
\hline Log Expenditure per Capita & & & $\begin{array}{c}-0.12^{* * *} \\
(0.020)\end{array}$ & $\begin{array}{c}-0.12^{* * *} \\
(0.020)\end{array}$ & $\begin{array}{l}0.093 \\
(0.27)\end{array}$ & $\begin{array}{c}-0.52^{* * *} \\
(0.075)\end{array}$ \\
\hline Main Sources of Income & & & $\begin{array}{c}0.00083 \\
(0.011)\end{array}$ & $\begin{array}{c}-0.00054 \\
(0.011)\end{array}$ & $\begin{array}{c}0.11 \\
(0.18)\end{array}$ & $\begin{array}{l}0.0045 \\
(0.060)\end{array}$ \\
\hline Muslim & & & $\begin{array}{l}0.030^{* * *} \\
(0.0086)\end{array}$ & $\begin{array}{l}0.032^{* * *} \\
(0.0087)\end{array}$ & $\begin{array}{l}0.42^{* * *} \\
(0.095)\end{array}$ & $\begin{array}{l}0.16^{* * *} \\
(0.040)\end{array}$ \\
\hline Multi Ethic & & & $\begin{array}{l}0.0086^{*} \\
(0.0050)\end{array}$ & $\begin{array}{l}0.012^{* *} \\
(0.0051)\end{array}$ & $\begin{array}{l}0.28^{* * *} \\
(0.070)\end{array}$ & $\begin{array}{l}-0.012 \\
(0.035)\end{array}$ \\
\hline Mosque & & & $\begin{array}{l}-0.00070 \\
(0.00079)\end{array}$ & $\begin{array}{l}-0.00060 \\
(0.00079)\end{array}$ & $\begin{array}{l}-0.0050 \\
(0.011)\end{array}$ & $\begin{array}{l}0.048^{* * *} \\
(0.0044)\end{array}$ \\
\hline Church & & & $\begin{array}{l}0.00092 \\
(0.0023)\end{array}$ & $\begin{array}{c}0.0012 \\
(0.0022)\end{array}$ & $\begin{array}{c}-0.014 \\
(0.021)\end{array}$ & $\begin{array}{c}-0.065^{\text {*** }} \\
(0.010)\end{array}$ \\
\hline $\begin{array}{l}N \\
R^{2}\end{array}$ & $\begin{array}{l}42663 \\
002\end{array}$ & 42663 & 41594 & 41594 & 20500 & 41594 \\
\hline $\begin{array}{l}R^{2} \\
\text { pseudo } R^{2}\end{array}$ & 0.002 & 0.357 & 0.357 & 03 & 0.693 & \\
\hline Estimation Method & LPM & LPM & LPM & LPM & Logit & Logit \\
\hline Village FE & Yes & Yes & Yes & Yes & Yes & No \\
\hline Year FE & No & Yes & Yes & Yes & Yes & Yes \\
\hline Urban * Year FE & No & No & No & Yes & Yes & Yes \\
\hline
\end{tabular}

${ }^{*}$ Notes: Robust standard errors in parentheses. Columns (1) - (4) are at the village levels. The unit of observation is at the village level. The dependent variable in this estimation is dummy variable for civic engagement activities at the village level. The years included in the regressions are 2008, 2011 and 2014. Column (5) is the coefficient for the fixed effects logit regression. Column (6) is the coefficient for the random effects logit regression. ${ }^{*} p<0.10,{ }^{* *}$ $p<0.05,{ }^{* * *} p<0.01$ 
Table 5: Instrumental Variable Estimations

\begin{tabular}{|c|c|c|c|c|c|c|}
\hline & $\begin{array}{c}1) \\
\text { Infrastructure } \\
\text { Program }\end{array}$ & $\begin{array}{c}(2) \\
\text { Infrastructure } \\
\text { Program }\end{array}$ & $\begin{array}{c}(3) \\
\text { Economic } \\
\text { Program }\end{array}$ & $\begin{array}{c}(4) \\
\text { Economic } \\
\text { Program }\end{array}$ & $\begin{array}{c}5) \\
\text { Civic } \\
\text { Engagement }\end{array}$ & $\begin{array}{c}6) \\
\text { Civic } \\
\text { Engagement }\end{array}$ \\
\hline Signal & $\begin{array}{l}0.39^{* *} \\
(0.19)\end{array}$ & $\begin{array}{l}0.37^{*} \\
(0.21)\end{array}$ & $\begin{array}{l}0.60^{* *} \\
(0.27)\end{array}$ & $\begin{array}{l}0.52^{*} \\
(0.29)\end{array}$ & $\begin{array}{c}1.43^{* * *} \\
(0.34)\end{array}$ & $\begin{array}{c}1.59^{* * *} \\
(0.40)\end{array}$ \\
\hline Male Leader & & $\begin{array}{r}-0.0046 \\
(0.011)\end{array}$ & & $\begin{array}{l}0.0076 \\
(0.013)\end{array}$ & & $\begin{array}{c}0.015 \\
(0.018)\end{array}$ \\
\hline Age & & $\begin{array}{c}0.00030 \\
(0.00043)\end{array}$ & & $\begin{array}{c}0.00029 \\
(0.00052)\end{array}$ & & $\begin{array}{c}-0.0022^{* * *} \\
(0.00072)\end{array}$ \\
\hline Years of Education & & $\begin{array}{c}0.0015 \\
(0.0016)\end{array}$ & & $\begin{array}{c}0.0019 \\
(0.0021)\end{array}$ & & $\begin{array}{c}-0.0087^{* * *} \\
(0.0030)\end{array}$ \\
\hline Log Population & & $\begin{array}{c}-0.069^{* * *} \\
(0.011)\end{array}$ & & $\begin{array}{c}-0.063^{* * *} \\
(0.016)\end{array}$ & & $\begin{array}{l}-0.051^{* *} \\
(0.022)\end{array}$ \\
\hline Log Expenditure per Capita & & $\begin{array}{l}-0.14^{* * *} \\
(0.038)\end{array}$ & & $\begin{array}{l}-0.18^{* * *} \\
(0.052)\end{array}$ & & $\begin{array}{l}-0.37^{* * *} \\
(0.072)\end{array}$ \\
\hline Main Sources of Income & & $\begin{array}{c}0.021 \\
(0.015)\end{array}$ & & $\begin{array}{r}0.00020 \\
(0.017)\end{array}$ & & $\begin{array}{c}0.034 \\
(0.021)\end{array}$ \\
\hline Muslim & & $\begin{array}{r}-0.0012 \\
(0.018)\end{array}$ & & $\begin{array}{c}0.020 \\
(0.024)\end{array}$ & & $\begin{array}{l}0.15^{* * *} \\
(0.033)\end{array}$ \\
\hline Multi Ethnic & & $\begin{array}{c}-0.030^{* * *} \\
(0.011)\end{array}$ & & $\begin{array}{c}-0.040^{* * *} \\
(0.015)\end{array}$ & & $\begin{array}{c}-0.064^{* * *} \\
(0.021)\end{array}$ \\
\hline Mosque & & $\begin{array}{c}0.0014 \\
(0.00088)\end{array}$ & & $\begin{array}{c}0.00099 \\
(0.00099)\end{array}$ & & $\begin{array}{l}-0.00024 \\
(0.0014)\end{array}$ \\
\hline Church & & $\begin{array}{l}-0.0022 \\
(0.0022)\end{array}$ & & $\begin{array}{l}-0.0056^{* *} \\
(0.0027)\end{array}$ & & $\begin{array}{l}-0.0015 \\
(0.0041)\end{array}$ \\
\hline$N$ & 42663 & 41561 & 42663 & 41561 & 42663 & 41561 \\
\hline Estimation Method & 2SLS & 2SLS & 2SLS & 2SLS & 2SLS & 2SLS \\
\hline Village FE & Yes & Yes & Yes & Yes & Yes & Yes \\
\hline Year FE & Yes & Yes & Yes & Yes & Yes & Yes \\
\hline $\begin{array}{l}\text { First Stage } \\
\text { Flash Rate Intensity X Time Trend }\end{array}$ & $\begin{array}{c}-0.001 * * * \\
(0.0001)\end{array}$ & $\begin{array}{c}-0.0009^{* * *} \\
(0.001)\end{array}$ & $\begin{array}{c}-0.001^{* * *} \\
(0.0002)\end{array}$ & $\begin{array}{c}-0.0009^{* * *} \\
(0.0002)\end{array}$ & $\begin{array}{c}-0.001^{* * *} \\
(0.0001)\end{array}$ & $\begin{array}{c}-0.0009^{* * *} \\
(0.0002)\end{array}$ \\
\hline$F$ & 26.06 & 22.46 & 26.06 & 22.46 & 26.06 & 22.46 \\
\hline
\end{tabular}

* Notes: The years included in the regressions are 2008, 2011 and 2014. Signal strength is instrumented by mean annual flash rate density per $\mathrm{km}^{2} .{ }^{*}$ $p<0.10,{ }^{* *} p<0.05,{ }^{* * *} p<0.01$ 
Table 6: Flash Rate Intensity and Outcome Variables

\begin{tabular}{lccc}
\hline & $\begin{array}{c}(1) \\
\text { Infrastructure } \\
\text { Program }\end{array}$ & $\begin{array}{c}(2) \\
\text { Economic } \\
\text { Program }\end{array}$ & $\begin{array}{c}(3) \\
\text { Civic } \\
\text { Engagement }\end{array}$ \\
\hline Flash Rate Intensity X Time Trend & -0.0000095 & -0.00020 & -0.00017 \\
& $(0.00019)$ & $(0.00026)$ & $(0.00024)$ \\
\hline$N$ & 41594 & 41594 & 41594 \\
$R^{2}$ & 0.480 & 0.220 & 0.306 \\
\hline$N$ & 41594 & 41594 & 41594 \\
\hline Estimation Method & LPM & LPM & LPM \\
Year X Island X Topography FE & Yes & Yes & Yes \\
Village FE & Yes & Yes & Yes \\
Controls & Yes & Yes & Yes \\
\hline
\end{tabular}

${ }^{*}$ Notes: ${ }^{*} p<0.10,{ }^{* *} p<0.05,{ }^{* * *} p<0.01$ 
Table 7: Treatment-effects Estimation: Propensity Score Matching

\begin{tabular}{lcccccc}
\hline & $\begin{array}{c}(1) \\
\text { Infrastructure } \\
\text { Program }\end{array}$ & $\begin{array}{c}\text { Infrastructure } \\
\text { Program }\end{array}$ & $\begin{array}{c}(3) \\
\text { Economic } \\
\text { Program }\end{array}$ & $\begin{array}{c}(4) \\
\text { Economic } \\
\text { Program }\end{array}$ & $\begin{array}{c}(5) \\
\text { Civic } \\
\text { Engagement }\end{array}$ & $\begin{array}{c}(6) \\
\text { Civic } \\
\text { Engagement }\end{array}$ \\
\hline Signal & $0.039^{*}$ & $0.012^{*}$ & $0.063^{* * *}$ & $0.03^{* * *}$ & $0.036^{*}$ & 0.006 \\
& $(0.020)$ & $(0.006)$ & $(0.018)$ & $(0.008)$ & $(0.022)$ & $(0.004)$ \\
\hline$N$ & 41594 & 41594 & 41594 & 41594 & 41594 & 41594 \\
\hline Estimation Method & NNM & Kernel & NNM & Kernel & NNM & Kernel \\
Year FE & Yes & Yes & Yes & Yes & Yes & Yes \\
Village FE & Yes & Yes & Yes & Yes & Yes & Yes \\
Controls & Yes & Yes & Yes & Yes & Yes & Yes \\
Geographical Controls & Yes & Yes & Yes & Yes & Yes & Yes
\end{tabular}

*Notes: The years included in the regressions are 2008, 2011 and 2014. The propensity matching results include a full set of control variables and additional geographical variables (topography, urban, paved road, land and distance to sub-district) and also village dummies. Standard error for the propensity results are Abadie-Imbens robust standard errors (Abadie and Imbens, 2016) for columns(1), (3) and (5) and bootstrap standard errors for columns (2), (4) and (6). ${ }^{*} p<0.10,{ }^{* *} p<0.05,{ }^{* * *} p<0.01$ 
Figure 8: (Weak) Overlap and Common Support Condition

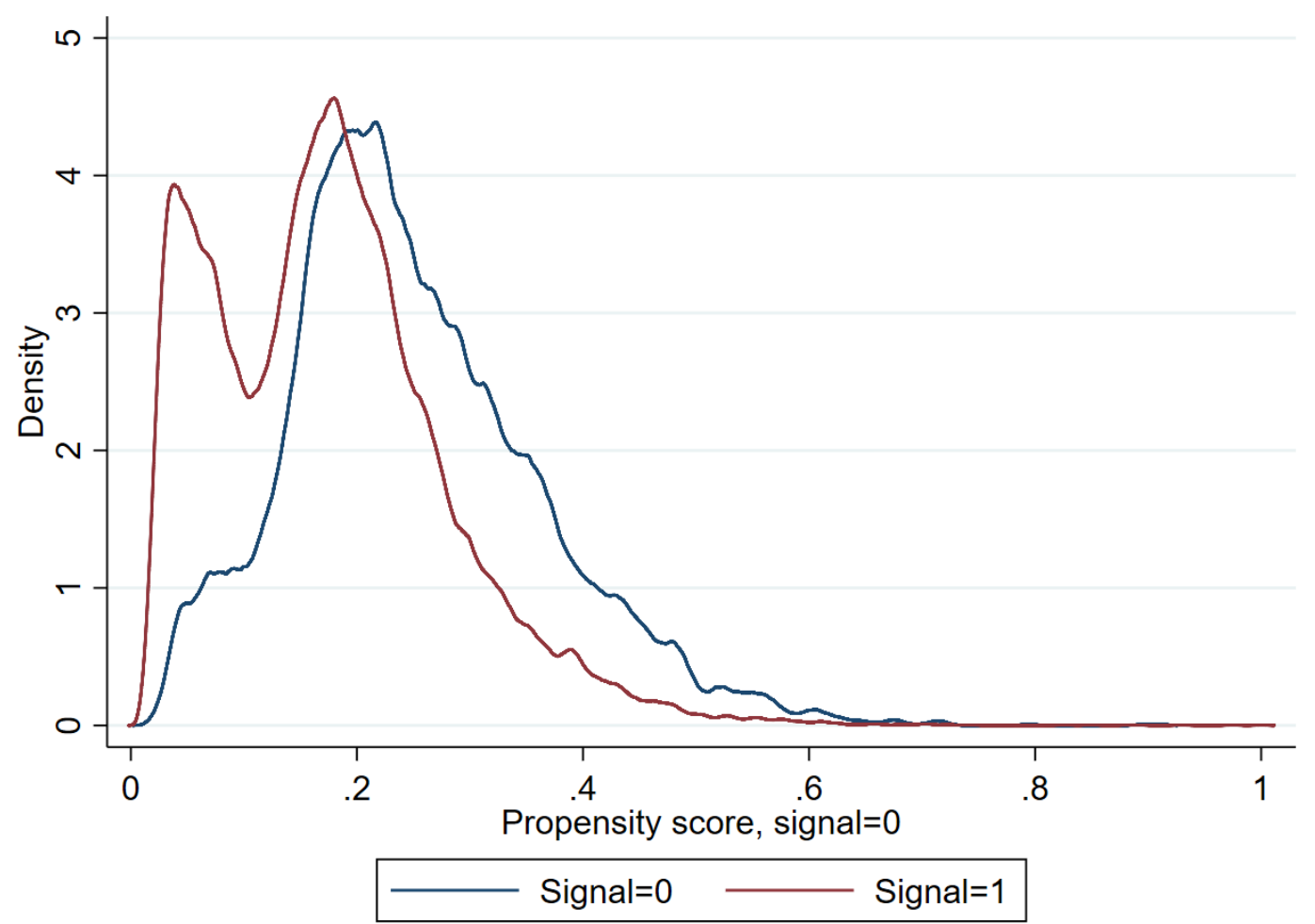


Table 8: Additional Results: Desa versus Kelurahan
(1)
(2)
(3)
$(4)$

Dependent Variable $=$ Infrastructure Program

\begin{tabular}{lcccc} 
Signal & $0.011^{*}$ & $0.61^{*}$ & 0.020 & 0.094 \\
& $(0.0063)$ & $(0.34)$ & $(0.031)$ & $(0.47)$ \\
\hline$N$ & 38026 & 37923 & 3568 & 3561 \\
$R^{2}$ & 0.466 & & 0.437 & \\
\hline
\end{tabular}

First Stage
Flash Rate Intensity
X Time Trend
F

$F$

$$
\begin{gathered}
-0.0017^{* * *} \\
(0.0004)
\end{gathered}
$$$$
-0.002^{* * *}
$$

12.62

14.22

\begin{tabular}{|c|c|c|c|c|}
\hline \multicolumn{5}{|l|}{ First Stage } \\
\hline Flash Rate Intensity & & $-0.0017^{* * *}$ & & $-0.002^{* * *}$ \\
\hline X Time Trend & & $(0.0004)$ & & $(0.0006)$ \\
\hline$F$ & & 12.62 & & 14.22 \\
\hline \multirow[b]{2}{*}{ Signal } & \multicolumn{4}{|c|}{ Dependent Variable $=$ Civic Engagement } \\
\hline & $\begin{array}{c}0.0041 \\
(0.0054)\end{array}$ & $\begin{array}{c}1.82^{* * * *} \\
(0.63)\end{array}$ & $\begin{array}{l}0.050^{*} \\
(0.029)\end{array}$ & $\begin{array}{l}0.97^{*} \\
(0.57)\end{array}$ \\
\hline$N$ & 38026 & 37923 & 3568 & 3561 \\
\hline$R^{2}$ & 0.404 & & 0.448 & \\
\hline
\end{tabular}

\begin{tabular}{lcccc}
\hline \multirow{3}{*}{ Signal } & \multicolumn{4}{c}{ Dependent Variable = Economic Program } \\
\cline { 2 - 5 } & $0.019^{* *}$ & 0.67 & 0.046 & 0.84 \\
& $(0.0076)$ & $(0.48)$ & $(0.032)$ & $(0.59)$ \\
\hline$N$ & 38026 & 37923 & 3568 & 3561 \\
$R^{2}$ & 0.298 & & 0.339 & \\
\hline
\end{tabular}

\begin{tabular}{lcccc}
\hline First Stage & & & \\
Flash Rate Intensity & & $-0.0017^{* * *}$ & & $-0.002^{* * *}$ \\
X Time Trend & & $(0.0004)$ & & $(0.0006)$ \\
$F$ & 12.62 & & 14.22 \\
\hline Estimation Method & LPM & 2SLS & LPM & 2SLS \\
Year* Topography FE & Yes & Yes & Yes & Yes \\
Sub-District FE & Yes & Yes & Yes & Yes \\
Controls & Yes & Yes & Yes & Yes \\
Sample & Desa & Desa & Kelurahan & Kelurahan
\end{tabular}

* Notes: Robust standard errors in parentheses and clustered at the sub-district. The unit of observation is at the village level. Signal strength is instrumented by flash rate intensity at the sub-district levels interacted with time trend. ${ }^{*} p<0.10,{ }^{* *} p<0.05,{ }^{* * *} p<0.01$ 
Table 9: Ordered Signal

\begin{tabular}{|c|c|c|c|c|c|c|}
\hline & $\begin{array}{c}(1) \\
\text { Infrastructure } \\
\text { Program } \\
\end{array}$ & $\begin{array}{c}(2) \\
\text { Infrastructure } \\
\text { Program } \\
\end{array}$ & $\begin{array}{c}(3) \\
\text { Economic } \\
\text { Program } \\
\end{array}$ & $\begin{array}{c}(4) \\
\text { Economic } \\
\text { Program } \\
\end{array}$ & $\begin{array}{c}\text { (5) } \\
\text { Civic } \\
\text { Engagement }\end{array}$ & $\begin{array}{c}\text { (6) } \\
\text { Civic } \\
\text { Engagement } \\
\end{array}$ \\
\hline Ordered Signal & $\begin{array}{c}0.011^{*} \\
(0.0059)\end{array}$ & $\begin{array}{l}0.25^{*} \\
(0.14)\end{array}$ & $\begin{array}{c}0.011 \\
(0.0068)\end{array}$ & $\begin{array}{l}0.35^{*} \\
(0.19)\end{array}$ & $\begin{array}{l}0.019^{* * *} \\
(0.0057)\end{array}$ & $\begin{array}{c}1.07^{* * *} \\
(0.22)\end{array}$ \\
\hline Male Leader & $\begin{array}{l}-0.0089 \\
(0.010)\end{array}$ & $\begin{array}{l}-0.0058 \\
(0.011)\end{array}$ & $\begin{array}{l}0.0015 \\
(0.012)\end{array}$ & $\begin{array}{l}0.0059 \\
(0.012)\end{array}$ & $\begin{array}{l}-0.0036 \\
(0.0092)\end{array}$ & $\begin{array}{c}0.010 \\
(0.015)\end{array}$ \\
\hline Age & $\begin{array}{c}0.00073^{* *} \\
(0.00033)\end{array}$ & $\begin{array}{c}0.00043 \\
(0.00038)\end{array}$ & $\begin{array}{l}0.00090^{* *} \\
(0.00037)\end{array}$ & $\begin{array}{c}0.00047 \\
(0.00045)\end{array}$ & $\begin{array}{l}-0.00035 \\
(0.00030)\end{array}$ & $\begin{array}{c}-0.0017^{* * *} \\
(0.00054)\end{array}$ \\
\hline Years of Education & $\begin{array}{c}0.0037^{* * *} \\
(0.0010)\end{array}$ & $\begin{array}{c}0.0021 \\
(0.0014)\end{array}$ & $\begin{array}{c}0.0049^{* * *} \\
(0.0012)\end{array}$ & $\begin{array}{c}0.0026 \\
(0.0017)\end{array}$ & $\begin{array}{c}0.00073 \\
(0.00097)\end{array}$ & $\begin{array}{c}-0.0064^{* * *} \\
(0.0021)\end{array}$ \\
\hline Log Population & $\begin{array}{c}-0.060^{* * *} \\
(0.0092)\end{array}$ & $\begin{array}{c}-0.064^{* * *} \\
(0.0099)\end{array}$ & $\begin{array}{c}-0.050^{* * *} \\
(0.013)\end{array}$ & $\begin{array}{c}-0.056^{* * *} \\
(0.014)\end{array}$ & $\begin{array}{l}-0.0099 \\
(0.0099)\end{array}$ & $\begin{array}{l}-0.029 \\
(0.018)\end{array}$ \\
\hline Log Expenditure per Capita & $\begin{array}{c}-0.089^{* * *} \\
(0.018)\end{array}$ & $\begin{array}{c}-0.14^{* * *} \\
(0.035)\end{array}$ & $\begin{array}{c}-0.10^{* * *} \\
(0.022)\end{array}$ & $\begin{array}{c}-0.18^{* * *} \\
(0.048)\end{array}$ & $\begin{array}{c}-0.12^{* * *} \\
(0.020)\end{array}$ & $\begin{array}{c}-0.35^{* * *} \\
(0.058)\end{array}$ \\
\hline Main Sources of Income & $\begin{array}{c}0.013 \\
(0.013)\end{array}$ & $\begin{array}{c}0.019 \\
(0.014)\end{array}$ & $\begin{array}{l}-0.011 \\
(0.015)\end{array}$ & $\begin{array}{l}-0.0014 \\
(0.016)\end{array}$ & $\begin{array}{c}0.00096 \\
(0.011)\end{array}$ & $\begin{array}{l}0.030^{*} \\
(0.017)\end{array}$ \\
\hline Muslim & $\begin{array}{c}-0.028^{* * *} \\
(0.0081)\end{array}$ & $\begin{array}{l}-0.0092 \\
(0.014)\end{array}$ & $\begin{array}{l}-0.018^{* *} \\
(0.0093)\end{array}$ & $\begin{array}{l}0.0082 \\
(0.018)\end{array}$ & $\begin{array}{l}0.030^{* * *} \\
(0.0086)\end{array}$ & $\begin{array}{l}0.11^{* * *} \\
(0.022)\end{array}$ \\
\hline Multi Ethnic & $\begin{array}{l}-0.014^{* *} \\
(0.0057)\end{array}$ & $\begin{array}{c}-0.027^{* * *} \\
(0.0092)\end{array}$ & $\begin{array}{l}-0.017^{* *} \\
(0.0065)\end{array}$ & $\begin{array}{c}-0.034^{* * *} \\
(0.012)\end{array}$ & $\begin{array}{l}0.0084^{*} \\
(0.0050)\end{array}$ & $\begin{array}{c}-0.047^{* * *} \\
(0.014)\end{array}$ \\
\hline Mosque & $\begin{array}{c}0.0012 \\
(0.00084)\end{array}$ & $\begin{array}{c}0.0012 \\
(0.00086)\end{array}$ & $\begin{array}{c}0.00085 \\
(0.00091)\end{array}$ & $\begin{array}{c}0.00085 \\
(0.00095)\end{array}$ & $\begin{array}{l}-0.00071 \\
(0.00079)\end{array}$ & $\begin{array}{c}-0.00072 \\
(0.0011)\end{array}$ \\
\hline Church & $\begin{array}{l}-0.0016 \\
(0.0021) \\
\end{array}$ & $\begin{array}{l}-0.0015 \\
(0.0022) \\
\end{array}$ & $\begin{array}{l}-0.0048^{*} \\
(0.0025)\end{array}$ & $\begin{array}{c}-0.0047^{*} \\
(0.0027) \\
\end{array}$ & $\begin{array}{l}0.00095 \\
(0.0023)\end{array}$ & $\begin{array}{c}0.0013 \\
(0.0037)\end{array}$ \\
\hline $\begin{array}{l}N \\
R^{2}\end{array}$ & $\begin{array}{l}41594 \\
0.467\end{array}$ & 41561 & $\begin{array}{l}41594 \\
0.213\end{array}$ & 41561 & $\begin{array}{l}41594 \\
0.357\end{array}$ & 41561 \\
\hline $\begin{array}{l}\text { Estimation Method } \\
\text { Village FE } \\
\text { Year FE }\end{array}$ & $\begin{array}{l}\text { LPM } \\
\text { Yes } \\
\text { No }\end{array}$ & $\begin{array}{l}\text { 2SLS } \\
\text { Yes } \\
\text { Yes }\end{array}$ & $\begin{array}{l}\text { LPM } \\
\text { Yes } \\
\text { No }\end{array}$ & $\begin{array}{l}\text { 2SLS } \\
\text { Yes } \\
\text { Yes }\end{array}$ & $\begin{array}{l}\text { LPM } \\
\text { Yes } \\
\text { Yes }\end{array}$ & $\begin{array}{l}\text { 2SLS } \\
\text { Yes } \\
\text { Yes }\end{array}$ \\
\hline $\begin{array}{l}\text { First Stage } \\
\text { Flash Rate Intensity } \\
\text { X Time Tredmd } \\
\text { F }\end{array}$ & & $\begin{array}{c}-0.0014^{* * *} \\
(0.0002) \\
37.32\end{array}$ & & $\begin{array}{c}-0.0014^{* * *} \\
(0.0002) \\
37.32\end{array}$ & & $\begin{array}{c}-0.0014^{* * *} \\
(0.0002) \\
37.32\end{array}$ \\
\hline
\end{tabular}

"Notes: The years included in the regressions are 2008, 2011 and 2014. Ordered signal equal to 2 if signal is strong, 1 if signal is weak and 0 if no signal. ${ }^{*} p<0.10,{ }^{* *} p<0.05,{ }^{* * *} p<0.01$ 
Table 10: Strong versus No Signal

\begin{tabular}{|c|c|c|c|c|c|c|}
\hline & $\begin{array}{c}(1) \\
\text { Infrastructure } \\
\text { Program }\end{array}$ & $\begin{array}{c}(2) \\
\text { Infrastructure } \\
\text { Program }\end{array}$ & $\begin{array}{c}(3) \\
\text { Economic } \\
\text { Program }\end{array}$ & $\begin{array}{c}(4) \\
\text { Economic } \\
\text { Program }\end{array}$ & $\begin{array}{c}\text { (5) } \\
\text { Civic } \\
\text { Engagement }\end{array}$ & $\begin{array}{c}(6) \\
\text { Civic } \\
\text { Engagement }\end{array}$ \\
\hline Strong Signal & $\begin{array}{c}0.013^{*} \\
(0.0069)\end{array}$ & $\begin{array}{c}0.013^{*} \\
(0.0070)\end{array}$ & $\begin{array}{l}0.018^{* *} \\
(0.0080)\end{array}$ & $\begin{array}{l}0.019^{* *} \\
(0.0081)\end{array}$ & $\begin{array}{l}0.016^{* *} \\
(0.0064)\end{array}$ & $\begin{array}{c}0.0082 \\
(0.0064)\end{array}$ \\
\hline Weak Signal & $\begin{array}{c}0.00091 \\
(0.018)\end{array}$ & $\begin{array}{l}0.0023 \\
(0.018)\end{array}$ & $\begin{array}{c}0.026 \\
(0.021)\end{array}$ & $\begin{array}{c}0.027 \\
(0.021)\end{array}$ & $\begin{array}{l}-0.036^{*} \\
(0.019)\end{array}$ & $\begin{array}{l}-0.035^{*} \\
(0.019)\end{array}$ \\
\hline Male Leader & $\begin{array}{l}-0.0089 \\
(0.010)\end{array}$ & $\begin{array}{l}-0.0088 \\
(0.011)\end{array}$ & $\begin{array}{l}0.0015 \\
(0.012)\end{array}$ & $\begin{array}{l}0.0016 \\
(0.012)\end{array}$ & $\begin{array}{c}-0.0036 \\
(0.0092)\end{array}$ & $\begin{array}{c}-0.0032 \\
(0.0092)\end{array}$ \\
\hline Age & $\begin{array}{c}0.00073^{* *} \\
(0.00033)\end{array}$ & $\begin{array}{c}0.00075^{* *} \\
(0.00033)\end{array}$ & $\begin{array}{c}0.00090^{* *} \\
(0.00037)\end{array}$ & $\begin{array}{c}0.00090^{* *} \\
(0.00037)\end{array}$ & $\begin{array}{l}-0.00035 \\
(0.00030)\end{array}$ & $\begin{array}{l}-0.00039 \\
(0.00030)\end{array}$ \\
\hline Years of Education & $\begin{array}{c}0.0037^{* * *} \\
(0.0010)\end{array}$ & $\begin{array}{c}0.0037^{* * *} \\
(0.0010)\end{array}$ & $\begin{array}{c}0.0049^{* * *} \\
(0.0012)\end{array}$ & $\begin{array}{c}0.0050^{* * *} \\
(0.0012)\end{array}$ & $\begin{array}{c}0.00074 \\
(0.00097)\end{array}$ & $\begin{array}{c}0.00023 \\
(0.00097)\end{array}$ \\
\hline Log Population & $\begin{array}{c}-0.060^{* * *} \\
(0.0092)\end{array}$ & $\begin{array}{c}-0.058^{* * *} \\
(0.0092)\end{array}$ & $\begin{array}{c}-0.050^{* * *} \\
(0.013)\end{array}$ & $\begin{array}{c}-0.050^{* * *} \\
(0.013)\end{array}$ & $\begin{array}{l}-0.0097 \\
(0.0099)\end{array}$ & $\begin{array}{l}-0.0097 \\
(0.0098)\end{array}$ \\
\hline Log Expenditure per Capita & $\begin{array}{c}-0.088^{* * *} \\
(0.018)\end{array}$ & $\begin{array}{c}-0.094^{* * *} \\
(0.018)\end{array}$ & $\begin{array}{c}-0.099^{* * *} \\
(0.022)\end{array}$ & $\begin{array}{c}-0.099 * * * \\
(0.022)\end{array}$ & $\begin{array}{c}-0.12^{* * *} \\
(0.020)\end{array}$ & $\begin{array}{c}-0.12^{* * *} \\
(0.020)\end{array}$ \\
\hline Main Sources of Income & $\begin{array}{c}0.013 \\
(0.013)\end{array}$ & $\begin{array}{c}0.014 \\
(0.013)\end{array}$ & $\begin{array}{l}-0.011 \\
(0.015)\end{array}$ & $\begin{array}{l}-0.010 \\
(0.015)\end{array}$ & $\begin{array}{l}0.0010 \\
(0.011)\end{array}$ & $\begin{array}{l}0.0013 \\
(0.011)\end{array}$ \\
\hline Muslim & $\begin{array}{c}-0.028^{* * *} \\
(0.0081)\end{array}$ & $\begin{array}{c}-0.028^{* * *} \\
(0.0081)\end{array}$ & $\begin{array}{c}-0.018^{*} \\
(0.0093)\end{array}$ & $\begin{array}{l}-0.017^{*} \\
(0.0093)\end{array}$ & $\begin{array}{l}0.030^{* * *} \\
(0.0086)\end{array}$ & $\begin{array}{l}0.026^{* * *} \\
(0.0086)\end{array}$ \\
\hline Multi Ethnic & $\begin{array}{l}-0.014^{* *} \\
(0.0057)\end{array}$ & $\begin{array}{l}-0.014^{* *} \\
(0.0057)\end{array}$ & $\begin{array}{c}-0.017^{* * *} \\
(0.0065)\end{array}$ & $\begin{array}{l}-0.016^{* *} \\
(0.0065)\end{array}$ & $\begin{array}{l}0.0085^{*} \\
(0.0050)\end{array}$ & $\begin{array}{c}0.0068 \\
(0.0050)\end{array}$ \\
\hline Mosque & $\begin{array}{c}0.0012 \\
(0.00084)\end{array}$ & $\begin{array}{c}0.0012 \\
(0.00084)\end{array}$ & $\begin{array}{c}0.00086 \\
(0.00091)\end{array}$ & $\begin{array}{c}0.00083 \\
(0.00091)\end{array}$ & $\begin{array}{l}-0.00071 \\
(0.00079)\end{array}$ & $\begin{array}{l}-0.00050 \\
(0.00079)\end{array}$ \\
\hline Church & $\begin{array}{c}-0.0017 \\
(0.0021)\end{array}$ & $\begin{array}{l}-0.0014 \\
(0.0021)\end{array}$ & $\begin{array}{l}-0.0049^{*} \\
(0.0025)\end{array}$ & $\begin{array}{c}-0.0049^{*} \\
(0.0025)\end{array}$ & $\begin{array}{l}0.00099 \\
(0.0022)\end{array}$ & $\begin{array}{c}0.0012 \\
(0.0022)\end{array}$ \\
\hline$N$ & 41594 & 41594 & 41594 & 41594 & 41594 & 41594 \\
\hline$R^{2}$ & 0.467 & 0.467 & 0.213 & 0.213 & 0.357 & 0.361 \\
\hline Estimation Method & LPM & LPM & LPM & LPM & LPM & LPM \\
\hline Village FE & Yes & Yes & Yes & Yes & Yes & Yes \\
\hline Year FE & Yes & Yes & Yes & Yes & Yes & Yes \\
\hline Topography * Year FE & No & Yes & No & Yes & No & Yes \\
\hline
\end{tabular}


Table 11: Effects on Household Telecommunication Expenditure

\begin{tabular}{lcccc}
\hline & $\begin{array}{c}(1) \\
\text { Log Communication } \\
\text { Expenditure }\end{array}$ & $\begin{array}{c}(2) \\
\text { Log Communication } \\
\text { Expenditure }\end{array}$ & $\begin{array}{c}(3) \\
\text { Log Communication } \\
\text { Expenditure }\end{array}$ & $\begin{array}{c}\text { Log Communication } \\
\text { Expenditure }\end{array}$ \\
\hline Signal Strength & $0.542^{* *}$ & $0.483^{* *}$ & $1.613^{* * *}$ & $1.380^{* *}$ \\
& $(0.224)$ & $(0.234)$ & $(0.554)$ & $(0.543)$ \\
\hline$N$ & 3703 & 3703 & 3798 & 3798 \\
$R^{2}$ & 0.0015 & 0.0243 & 0.0072 & 0.0379 \\
\hline Estimation Method & OLS & OLS & OLS & OLS \\
Sub District FE & Yes & Yes & Yes & Yes \\
Household FE & No & No & No & Yes \\
Controls & No & Yes & & \\
\hline
\end{tabular}

* Notes: The dependent variable is log total household expenditures for telecommunication. The table uses Indonesian Family Life Survey (IFLS) rounds 4 and 5 in 2007 and 2014, respectively. The unit of observations is number of household. Controls variable included household home ownership $(1=$ self owned, $0=$ otherwise $)$, access to electricity $(1=$ have access, $0=$ otherwise $)$ and access to TV $(1=$ have TV, $0=$ otherwise). ${ }^{*} p<0.10,{ }^{* *} p<0.05,{ }^{* * *} p<0.01$

Table 12: Neighbouring Effects

\begin{tabular}{lcccccc}
\hline & $\begin{array}{c}(1) \\
\text { Infrastructure } \\
\text { Program }\end{array}$ & $\begin{array}{c}(2) \\
\text { Infrastructure } \\
\text { Program }\end{array}$ & $\begin{array}{c}(3) \\
\text { Economic } \\
\text { Program }\end{array}$ & $\begin{array}{c}(4) \\
\text { Economic } \\
\text { Program }\end{array}$ & $\begin{array}{c}(5) \\
\text { Civic } \\
\text { Engagement }\end{array}$ & $\begin{array}{c}(6) \\
\text { Civic } \\
\text { Engagement }\end{array}$ \\
\hline Neighbour Signal Strength & $0.093^{* * *}$ & $0.093^{* * *}$ & $0.058^{* * *}$ & $0.055^{* * *}$ & $0.081^{* * *}$ & $0.10^{* * *}$ \\
& $(0.017)$ & $(0.017)$ & $(0.020)$ & $(0.021)$ & $(0.016)$ & $(0.017)$ \\
Signal Strength & 0.0024 & 0.0024 & 0.011 & 0.011 & 0.0054 & 0.0091 \\
& $(0.0068)$ & $(0.0068)$ & $(0.0079)$ & $(0.0081)$ & $(0.0064)$ & $(0.0065)$ \\
\hline$N$ & 42663 & 42663 & 42663 & 41594 & 42663 & 41594 \\
$R^{2}$ & 0.472 & 0.472 & 0.213 & 0.213 & 0.358 & 0.358 \\
\hline Estimation Method & OLS & OLS & OLS & OLS & OLS & OLS \\
Village Fixed Effects & Yes & Yes & Yes & Yes & Yes & Yes \\
Year Fixed Effects & Yes & Yes & Yes & Yes & Yes & Yes \\
Controls & No & Yes & No & Yes & No & Yes \\
\hline
\end{tabular}

* Notes: The years included in the regressions are 2008, 2011 and 2014. Neighbour signal strength is the neighbouring signal strength within the same sub-district. ${ }^{*} p<0.10,{ }^{* *} p<0.05,{ }^{* * *} p<0.01$ 


\section{Appendix A Online Appendix}

Figure A1: Base Transceiver Tower at Village Level in 2014

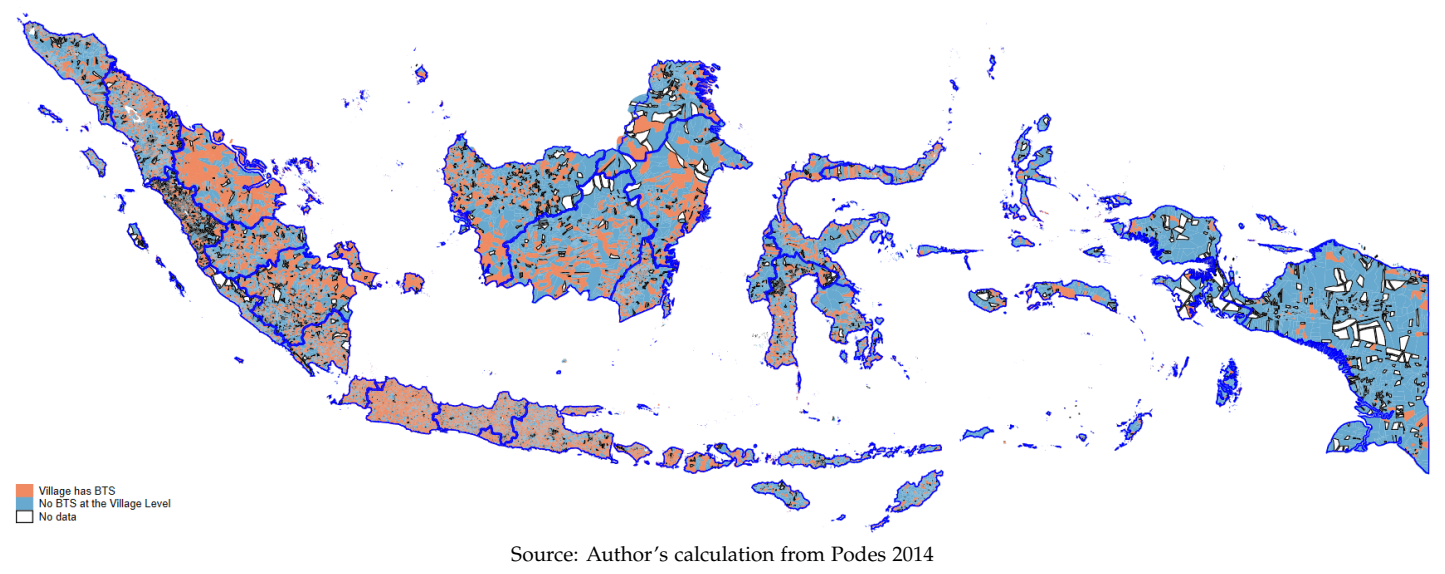

Figure A2: Base Transceiver Tower at Village Level in 2011

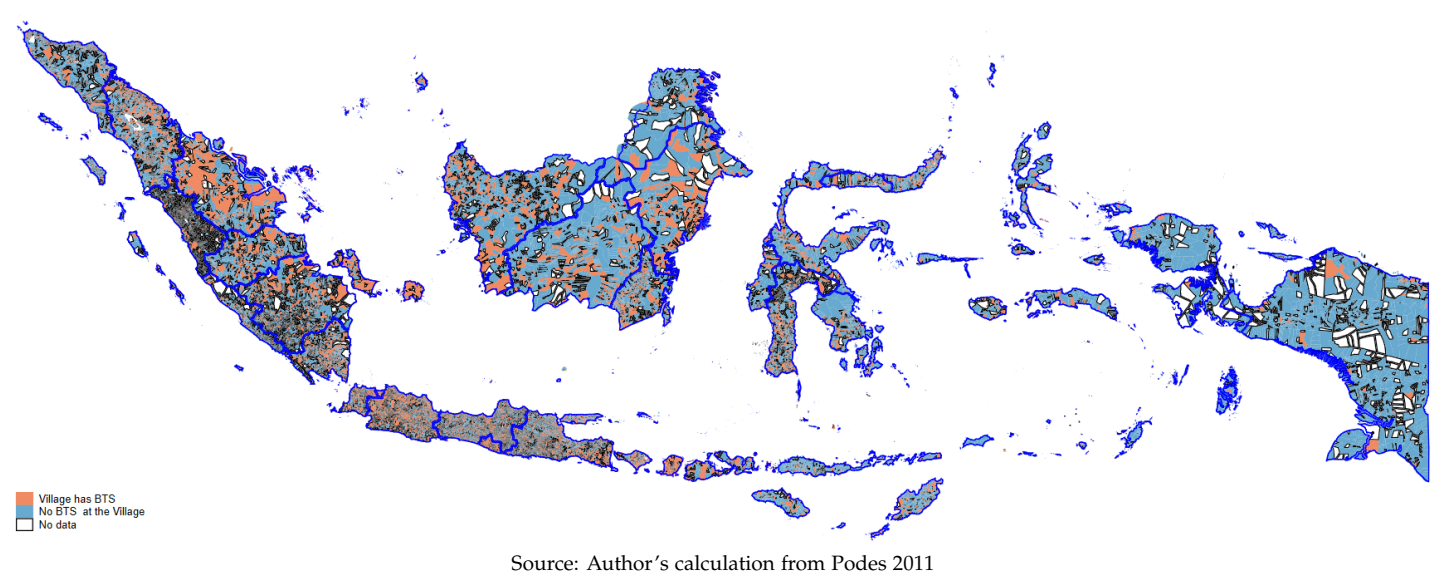


Table A1: Correlates of Signal Strength in Indonesia

\begin{tabular}{|c|c|c|c|c|}
\hline & $\begin{array}{c}(1) \\
\text { Signal }\end{array}$ & $\begin{array}{c}(2) \\
\text { BTS Presence }\end{array}$ & $\begin{array}{c}(3) \\
\text { Signal }\end{array}$ & $\begin{array}{c}(4) \\
\text { BTS Presence }\end{array}$ \\
\hline Log Population & $\begin{array}{c}0.035^{* * *} \\
(0.013)\end{array}$ & $\begin{array}{l}0.021^{*} \\
(0.011)\end{array}$ & $\begin{array}{c}0.038^{* * *} \\
(0.013)\end{array}$ & $\begin{array}{l}0.019^{*} \\
(0.011)\end{array}$ \\
\hline Log Expenditure per Capita & $\begin{array}{l}0.061^{* * *} \\
(0.0078)\end{array}$ & $\begin{array}{l}0.086^{* * *} \\
(0.0057)\end{array}$ & $\begin{array}{l}0.14^{* * *} \\
(0.019)\end{array}$ & $\begin{array}{l}0.032^{* *} \\
(0.013)\end{array}$ \\
\hline Main Sources of Income & $\begin{array}{l}-0.021^{* *} \\
(0.0098)\end{array}$ & $\begin{array}{c}-0.024^{* * *} \\
(0.0091)\end{array}$ & $\begin{array}{l}-0.024^{* *} \\
(0.0097)\end{array}$ & $\begin{array}{l}-0.020^{* *} \\
(0.0090)\end{array}$ \\
\hline Muslim & $\begin{array}{c}-0.052^{* * *} \\
(0.0066)\end{array}$ & $\begin{array}{c}-0.020^{* * *} \\
(0.0033)\end{array}$ & $\begin{array}{c}-0.060^{* * *} \\
(0.0079)\end{array}$ & $\begin{array}{c}0.0026 \\
(0.0036)\end{array}$ \\
\hline Multi Ethnic & $\begin{array}{l}0.045^{* * *} \\
(0.0050)\end{array}$ & $\begin{array}{l}-0.0043 \\
(0.0032)\end{array}$ & $\begin{array}{l}0.043^{* * *} \\
(0.0050)\end{array}$ & $\begin{array}{c}0.0016 \\
(0.0033)\end{array}$ \\
\hline Mosque & $\begin{array}{l}-0.00031 \\
(0.00069)\end{array}$ & $\begin{array}{c}0.00052 \\
(0.00038)\end{array}$ & $\begin{array}{l}-0.00023 \\
(0.00069)\end{array}$ & $\begin{array}{c}0.00039 \\
(0.00038)\end{array}$ \\
\hline Church & $\begin{array}{c}0.0012 \\
(0.0020)\end{array}$ & $\begin{array}{l}-0.00099 \\
(0.0017)\end{array}$ & $\begin{array}{l}0.00097 \\
(0.0020)\end{array}$ & $\begin{array}{c}-0.00053 \\
(0.0017)\end{array}$ \\
\hline Electricity Ratio & $\begin{array}{c}0.013 \\
(0.013)\end{array}$ & $\begin{array}{l}0.027^{*} \\
(0.016)\end{array}$ & $\begin{array}{l}0.023^{*} \\
(0.013)\end{array}$ & $\begin{array}{c}0.014 \\
(0.015)\end{array}$ \\
\hline Accessed by Land & $\begin{array}{l}0.11^{* * *} \\
(0.019)\end{array}$ & $\begin{array}{c}0.0034 \\
(0.0094)\end{array}$ & $\begin{array}{l}0.11^{* * *} \\
(0.019)\end{array}$ & $\begin{array}{c}0.0075 \\
(0.0093)\end{array}$ \\
\hline Asphalt Road & $\begin{array}{c}0.13^{* * *} \\
(0.0067)\end{array}$ & $\begin{array}{c}0.0019 \\
(0.0036)\end{array}$ & $\begin{array}{c}0.13^{* * *} \\
(0.0068)\end{array}$ & $\begin{array}{c}0.0040 \\
(0.0036)\end{array}$ \\
\hline$N$ & 42663 & 42663 & 42663 & 42663 \\
\hline$R^{2}$ & 0.032 & 0.016 & 0.034 & 0.024 \\
\hline $\begin{array}{l}\text { Estimation Method } \\
\text { Village FE } \\
\text { Year FE }\end{array}$ & $\begin{array}{l}\text { OLS } \\
\text { Yes } \\
\text { No }\end{array}$ & $\begin{array}{l}\text { OLS } \\
\text { Yes } \\
\text { No }\end{array}$ & $\begin{array}{l}\text { OLS } \\
\text { Yes } \\
\text { Yes }\end{array}$ & $\begin{array}{l}\text { OLS } \\
\text { Yes } \\
\text { Yes }\end{array}$ \\
\hline
\end{tabular}


Table A2: Comparison of Means by Mobile Phone Signal in 2005

\begin{tabular}{|c|c|c|c|}
\hline & $\begin{array}{c}(1) \\
\text { Signal }=0 \\
(\mathrm{SD})\end{array}$ & $\begin{array}{c}(2) \\
\text { Signal }=1 \\
(\mathrm{SD})\end{array}$ & $\begin{array}{c}(3) \\
\text { Difference in Means } \\
(\mathrm{SE})\end{array}$ \\
\hline Top Slope & $\begin{array}{c}0.209 \\
(0.406)\end{array}$ & $\begin{array}{c}0.215 \\
(0.411)\end{array}$ & $\begin{array}{l}-0.005^{*} \\
(0.003)\end{array}$ \\
\hline Valley & $\begin{array}{c}0.072 \\
(0.260)\end{array}$ & $\begin{array}{c}0.075 \\
(0.263)\end{array}$ & $\begin{array}{l}-0.002 \\
(0.002)\end{array}$ \\
\hline Coastal & $\begin{array}{c}0.135 \\
(0.341)\end{array}$ & $\begin{array}{c}0.135 \\
(0.341)\end{array}$ & $\begin{array}{c}0.00009 \\
(0.002)\end{array}$ \\
\hline Forest & $\begin{array}{c}0.040 \\
(0.198)\end{array}$ & $\begin{array}{c}0.040 \\
(0.196)\end{array}$ & $\begin{array}{l}0.0005 \\
(0.001)\end{array}$ \\
\hline Natural Disaster Risk & $\begin{array}{c}0.320 \\
(0.466)\end{array}$ & $\begin{array}{c}0.315 \\
(0.464)\end{array}$ & $\begin{array}{c}0.005 \\
(0.003)\end{array}$ \\
\hline Main Income Source & $\begin{array}{c}0.011 \\
(0.106)\end{array}$ & $\begin{array}{c}0.012 \\
(0.111)\end{array}$ & $\begin{array}{c}-0.001 \\
(0.0008)\end{array}$ \\
\hline Log Population & $\begin{array}{c}14.69 \\
(2.380)\end{array}$ & $\begin{array}{c}14.85 \\
(2.350)\end{array}$ & $\begin{array}{c}-0.162^{* * *} \\
(0.018)\end{array}$ \\
\hline Distance to District & $\begin{array}{l}49.604 \\
(32.45)\end{array}$ & $\begin{array}{c}22.09 \\
(21.84)\end{array}$ & $\begin{array}{c}27.50^{* * *} \\
(0.219)\end{array}$ \\
\hline Paved Road & $\begin{array}{c}0.423 \\
(0.494)\end{array}$ & $\begin{array}{c}0.751 \\
(0.432)\end{array}$ & $\begin{array}{c}-0.328^{* * *} \\
(0.003)\end{array}$ \\
\hline Electricity & $\begin{array}{c}0.010 \\
(0.102)\end{array}$ & $\begin{array}{c}0.011 \\
(0.106)\end{array}$ & $\begin{array}{l}-0.0008 \\
(0.0008)\end{array}$ \\
\hline
\end{tabular}

${ }^{*}$ Notes: The years included in the regressions are 2005. Some of the covariates from Podes 2011 onwards are not available, e.g. BTS location. Moreover data related to expenditure are not available in Podes 2005, therefore I use dummy for income sources (1 if from telecommunication and service sectors and 0 otherwise) as the alternative covariate to control the level of income. ${ }^{*} p<0.10,{ }^{* *} p<0.05,{ }^{* * *} p<0.01$ 